\title{
Development of Calanus euxinus during spring cold homothermy in the Black Sea
}

\author{
Leonid S. Svetlichny ${ }^{1, *}$, Tatyana V. Yuneva ${ }^{1}$, Elena S. Hubareva ${ }^{1}$, \\ Alla M. Schepkina ${ }^{1}$, Sengul Besiktepe ${ }^{2}$, Ahmet E. Kideys ${ }^{2}$, Levent Bat ${ }^{3}$, Fatih Sahin ${ }^{3}$ \\ ${ }^{1}$ Institute of Biology of the Southern Seas, 99011 Sevastopol, Ukraine \\ ${ }^{2}$ Institute of Marine Sciences, Middle East Technical University, Erdemli 33731 Mersin, Turkey \\ ${ }^{3}$ Sinop University Fisheries Faculty Department of Hydrobiology, 57000 Sinop, Turkey
}

\begin{abstract}
In copepodites and adults of Calanus euxinus abundance, body length and weight, chemical composition and respiration rate in relation to age were studied during the cruise of R/V 'Knorr' in April 2003 in the southwestern Black Sea and in laboratory experiments. Data on morphology and physiology of $C$. euxinus collected during other seasons were also used in comparative analyses. At high concentrations of the diatom Proboscia alata during spring homothermy (6.8 to $8.5^{\circ} \mathrm{C}$ ) C. euxinus did not undertake diel vertical migrations to the oxygen minimum zone (OMZ). The majority of the population was located above the OMZ, feeding on phytoplankton during nighttime and daytime whilst nearly $10 \%$ of copepodite stages IV and V (CIV and CV) and adults remained constantly in the OMZ. Although a diapausing stock of the population began to form in the OMZ, the majority of $\mathrm{CV}$ developed without diapause. The development times of copepodite stages at $8^{\circ} \mathrm{C}$ were determined on the basis of field observations of ontogenetic changes in carbon content and calculated absolute growth rates. Development time from CI to CV amounted to $22 \mathrm{~d}$. In CV the time for lipid deposition from $0.008 \pm 0.007 \mathrm{~mm}^{3}$ in postmolts up to a maximum volume of $0.165 \pm$ $0.054 \mathrm{~mm}^{3}$ in intermolts constituted $26 \mathrm{~d}$. The total generation time from eggs to adults is not less than about $66 \mathrm{~d}$.
\end{abstract}

KEY WORDS: Calanus euxinus $\cdot$ Lipid storage $\cdot$ Respiration $\cdot$ Growth $\cdot$ Black Sea $\cdot$ Spring cold Homothermy

Resale or republication not permitted without written consent of the publisher

\section{INTRODUCTION}

The study of morphological and physiological diversity among populations of one species is necessary for understanding the processes of marine speciation and intraspecific adaptation strategies of the genus Calanus. Calanus in the Black Sea was first identified by Karavaev (1894) and named Calanus finmarchicus var. pontica. Jaschnov (1955) pointed out the separate status of C. finmarchicus and C. helgolandicus, and distinguished the Black Sea population as a subspecies, namely Calanus helgolandicus var. ponticus. Later, Fleminger \& Hulsemann (1987) proposed giving the Black Sea population the rank of separate species and the name of Calanus ponticus Karavaev. Finally, a new name Calanus euxinus was given to this species as a re- placement name for C. ponticus (Hulsemann 1991). However, Papadopoulos et al. (2005) and Unal et al. (2006) showed that genetic differences between $C$. euxinus and $C$. helgolandicus are extremely subtle and typical for conspecific populations.

Calanus helgolandicus inhabit mainly neritic waters and have an extremely wide geographical distribution range from the eastern North Atlantic and the North Sea southwards to the Mediterranean basin (Fleminger \& Hulsemann 1987).

Fleminger \& Hulsemann (1987) consider the Black Sea Calanus to be a phenetic population of $C$. helgolandicus which penetrated into the Black Sea from the Mediterranean Sea 7000 yr ago after the Dardanelles and the Bosphorus straits formed. According to an- 
other hypothesis, Calanus, like other 'boreal relicts', entered the Black Sea when it was connected with the North Sea across Europe during the period of retreating glaciers (Zaitsev 2006). This is in agreement with the results of Papadopoulos et al. (2005) suggesting that the divergences between the northeastern Atlantic, Mediterranean and Black Sea C. helgolandicus populations are much older than the estimated dates of colonization of the Mediterranean and Black Seas. However, according to Polischuk (1984) the last connection between the North and Black Seas could have been in the Late Holocene (2800 to 2700 BP).

Calanus euxinus is a dominant component of the zooplankton biomass in the Rim Current system of the Black Sea. The ecology of this species differs significantly from that of C. helgolandicus in other European seas due to the characteristics of the basin.

Calanus helgolandicus typically inhabits saline waters (32 to $39 \%$ ) with temperatures of 9 to $20^{\circ} \mathrm{C}$. This wide range is mainly due to seasonal variation; the temperature does not range widely between populations. Seasonal changes in abundance of $C$. helgolandicus are positively correlated with temperature (Bonnet et al. 2005) and food availability (Rey-Rassat et al. 2004). Overwintering $C$. helgolandicus descend to deep water and are separated spatially from the part of the population that develops in surface layers.

In contrast, Calanus euxinus has adapted to the low salinity of the Black Sea waters (18 to $20 \%$ ). Preadults and adults performing diel vertical migrations within the aerobic layer ( 0 to $150 \mathrm{~m}$ ) to the oxygen minimum zone (OMZ) undergo temperature changes within the range 6.5 to $22^{\circ} \mathrm{C}$ during warm seasons (Besiktepe et al. 1998, Besiktepe et al. 2005) but in winter and spring live at 5 to $8.5^{\circ} \mathrm{C}$. In deep waters the abundance of $C$. euxinus does not differ significantly between warm and cold seasons (Sazhina 1987). During the daytime, the migrating part of the population ascends to depths close to the layers where diapausing Calanus live, probably mixing with them. Prosome length of females from the Black Sea population is similar to (or may even exceed) the maximum prosome length of C. helgolandicus $(2.6 \mathrm{~mm})$ in the North Sea (Bonnet et al. 2005).

During summer and autumn, temperature stratification and low phytoplankton concentration in the water column cause late development stages of $C$. euxinus to reduce energy expenditure 7.2-fold through diel vertical migration from warm upper layers to the cold OMZ, thus using the energy of food consumed at night near the surface more efficiently (Svetlichny et al. 1998, 2006, Yuneva et al. 1999). Under hypoxic conditions during the daytime the catabolism of lipids is depressed whilst the synthesis of fatty alcohols from non-lipid components in the oil sac may be facilitated (Sargent \& McIntosh 1974).
Previous studies have focused on the life cycle, feeding and migration behavior (Petipa 1981, Vinogradov et al. 1992a,b), duration of development (Sazhina 1987), gonad maturation, lipid deposition and molting patterns (Arashkevich et al. 1998), growth, grazing and egg production rates (Sazhina 1987, Besiktepe \& Telli 2004, Besiktepe 2001), and lipid content and composition as indicators of nutritional condition of $C$. euxinus (Yuneva et al. 1997, 1999). However, this research has mostly been conducted in warm seasons and very few studies (e.g. Sazhina 1987, Vinogradov et al. 1992c) have investigated the development of $C$. euxinus during cold seasons. Among these studies, the research of Sazhina (1987) was a laboratory study and Vinogradov et al. (1992c) did not present sufficient details of the species development.

The present study analyzed the Calanus euxinus population age structure, abundance, dynamics of prosome length $\left(L_{\mathrm{p}}\right)$, body $\left(V_{\mathrm{b}}\right)$ and oil sac $\left(V_{\mathrm{s}}\right)$ volumes, molt phase patterns (in copepodite stages III to V [CIII to CV] only), defatted dry weight (DFDW), total lipid (TL) and wax ester (WE) concentrations, and changes in respiration rate during the cold period of early spring homothermy. These results were compared to morphological and physiological data for $C$. euxinus collected in the summer to autumn water stratification period. On the basis of data obtained in the present study and data from previous studies, we estimated growth rate and development time for copepodite stages of $C$. euxinus at a constant temperature of $8^{\circ} \mathrm{C}$ and tested the consistency of calculated absolute growth rates with metabolic rates.

\section{MATERIALS AND METHODS}

Zooplankton samples were collected with a Nansen closing net (opening diameter $71 \mathrm{~cm}$, mesh size $112 \mu \mathrm{m}$ ) during a cruise of the R/V 'Knorr' between 17 and 23 April 2003 at 3 deep stations in the southwestern Black Sea (Fig. 1). One station was located in the cyclonic zone with a depth of $2160 \mathrm{~m}$ (Stn 5, 17 April, $01: 30 \mathrm{~h}$ ) and 2 stations were in the anticyclonic region with depths of $845 \mathrm{~m}$ (Stn 7,18 April, 18:50 h) and $900 \mathrm{~m}$ (Stn 17, 22 April, 22:15 h). At all stations zooplankton was sampled by vertical hauls from the depth of the upper border of the anoxic zone with $\sigma_{\mathrm{t}}=16.2$ $(86,191$ and $185 \mathrm{~m}$ for Stns 5, 7 and 17, respectively) to the surface. At Stn 7 (18:30 h) and Stn 17 (22 April, 22:30 h, and 23 April, 11:30 h, respectively) additional tows were made in the OMZ with $15.4<\sigma_{\mathrm{t}}<16.2$. Further tows were made in the upper horizon of 0 to $60 \mathrm{~m}$ at Stns 5 and 17 during the daytime. The filtered volume was calculated from the wire length and the opening area of the net. Water temperature, salinity 


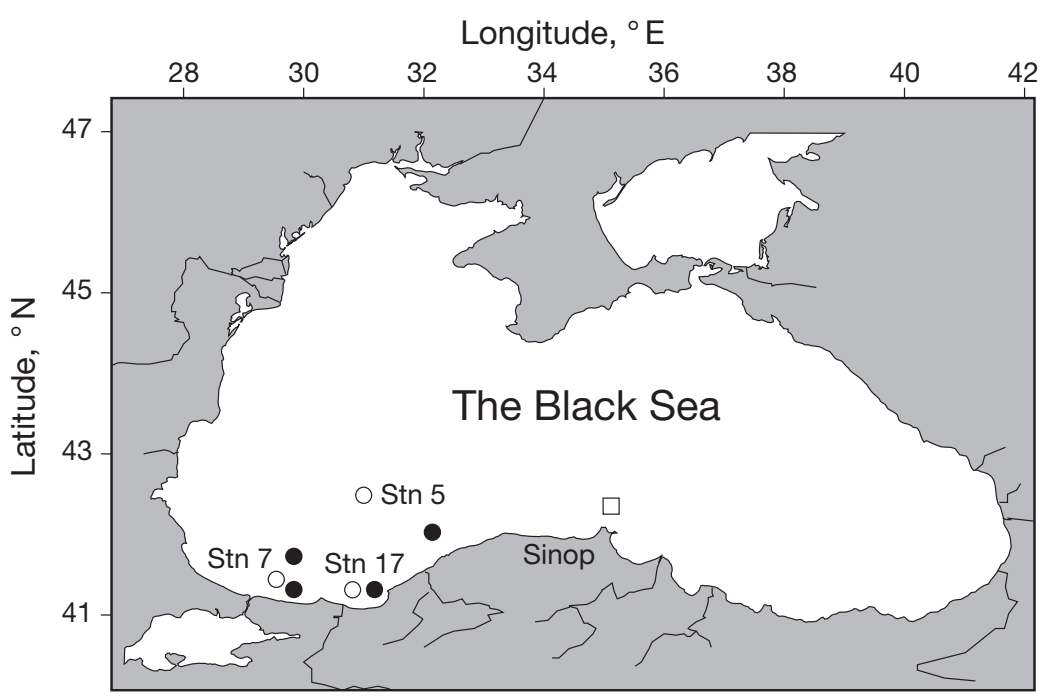

Fig. 1. Location of sampling stations in the Black Sea during the cruise (16 to 22 April 2003) of the R/V 'Knorr' (O), during the cruises (July 2000 and June 2001) of R/V 'Bilim' (@), and the monitoring station near Sinop in 1999 ( $\square$ )

$V_{\mathrm{b}}\left(\mathrm{mm}^{3}\right)$ was calculated as $V_{\mathrm{b}}=\mathrm{k} L_{\mathrm{p}}$ $D_{\mathrm{p}}{ }^{2}$, where $\mathrm{k}$ is the empiric coefficient of 0.64 in males and 0.58 in females and copepodites (Svetlichny 1983). $V_{\mathrm{s}}\left(\mathrm{mm}^{3}\right)$ was determined as the ellipsoid volume: $V_{\mathrm{s}}=\pi / 6 L_{\mathrm{s}} D_{\mathrm{s}}{ }^{2}$.

Wet weight (WW) of Calanus euxinus copepodites and females was calculated as $\mathrm{WW}=V_{\mathrm{b}} \rho$, where $\rho\left(\mathrm{g} \mathrm{cm}^{-3}\right)$ is the average body density determined using the equation $\rho=1.06-0.0016 \mathrm{SV}_{\mathrm{s}}$ (Svetlichny et al. 1998), where $\mathrm{SV}_{\mathrm{s}}(\%)$ is the proportion of the oil sac in body volume.

To determine lipid content, copepodites and adults were selected and sorted on board the ship. Batches of individuals (50 to 100 ind. for CI to CIII, 30 to 50 for CIV, 15 to 25 for CV, and 5 to 10 for adults) were transferred into glass vials with screw caps containing $5 \mathrm{ml}$ of chloroform/ methanol (2:1 by volume) where $0.01 \%$

and in situ fluorescence were measured using a Sea Bird CTD probe with attached Chelsea ${ }^{\mathrm{TM}}$ fluorometers.

Additional zooplankton samples were collected by vertical hauls from $180 \mathrm{~m}$ to the surface at the monitoring station near Sinop in January, February, March, May, September and November 1999. Other samples obtained in the southwestern Black Sea during the cruises of the R/V 'Bilim' in July 2000 and June 2001, using the same methodology, were also utilized for comparative analyses.

The samples were immediately preserved with $4 \%$ borax-buffered formaldehyde. In the laboratory each sample was divided into several portions and then the specimens of each copepodite stage of Calanus euxinus were counted using a Bogorov chamber under a dissecting microscope. When possible, 30 to 40 (up to 187 from Stn 7) individuals of each copepodite stage or adults were selected and measured for body size and oil sac volume, and for jaw phase identification (in CIII to $\mathrm{CV}$ only) according to tooth formation inside the gnathobases of mandibles.

After measuring body size and oil sac volume, the mandibles were dissected from the whole copepodite in a drop of 1:1 glycerol:water solution and 5 phases of moulting cycle (postmolt, $\mathrm{PO}$; late postmolt, LPO; intermolt, IN; early premolt, EPR; and premolt, PR) were determined according to tooth development (Marker et al. 2003, Johnson 2004). In the case of insufficient numbers of representatives of particular jaw phases the data were combined for phases PO and LPO and for EPR and PR.

Length and width of prosome $\left(L_{\mathrm{p}}\right.$ and $D_{\mathrm{p}}[\mathrm{mm}]$ and oil sack ( $L_{\mathrm{s}}$ and $D_{\mathrm{s}}[\mathrm{mm}]$ ) were measured to the nearest $10 \mu \mathrm{m}$ under a dissecting microscope fitted with an eyepiece micrometer. butylated hydroxytoluene was added as antioxidant (Folch et al. 1957) and extracted twice for $24 \mathrm{~h}$ without preliminary homogenization (Ohman 1988, Håkanson 1989). Between analytical procedures the resulting extracts were stored for about $2 \mathrm{wk}$ at $-20^{\circ} \mathrm{C}$ and then used for further qualitative and quantitative lipid content determination in the laboratory. The sulfovanillin technique (Barnes \& Blackstock 1973) was applied to define the content of TL in extracts. Lipids extracted from Calanus euxinus $\mathrm{CV}$, dried under vacuum and weighed on a Cahn electrobalance according to Kates (1975), were used as a standard for calibration.

The lipids were fractionated by unidimensional thinlayer chromatography on $5 \times 15 \mathrm{~cm}$ Silufoll UW254 plates (Kavalier) using solvents of different polarity. A chromatography chamber was used in which 3 cylindrical chambers of different sizes were nested (Yuneva et al. 1999). The outer chamber (diameter $15 \mathrm{~cm}$, height $21 \mathrm{~cm}$ ) was saturated with hexane for $2 \mathrm{~h}$ prior to fractionation, the intermediate chamber (diameter $7 \mathrm{~cm}$, height $13.5 \mathrm{~cm}$ ) was saturated with hexane/diethyl ether $(9: 1 \mathrm{v} / \mathrm{v})$ mixture, while the innermost chamber (diameter $5.5 \mathrm{~cm}$, height $1.0 \mathrm{~cm}$ ) contained chloroform.

The plates were activated at $105^{\circ} \mathrm{C}$ for $30 \mathrm{~min}$ and treated with a $10 \%$ solution of phosphomolybdenic acid in ethanol before the chromatography procedure. A 20 to $50 \mu \mathrm{g}$ sample of lipid was applied to each plate under nitrogen. The chambers were quickly assembled concentrically each other and a plate was immediately put into the innermost chamber. Thus, the plate was developed in solvents with decreasing polarity for $10 \mathrm{~min}$. Chromatograms were visualized by heating at $110^{\circ} \mathrm{C}$ for $7 \mathrm{~min}$ and quantified densitometrically using an ERS densitometer (Karl Zeiss). Lipid classes (phos- 
pholipids, sterol, free fatty acids and triacylglycerols; the results concerning these lipid classes are not included in the present paper) and WE were identified against a suite of lipid standards (Sigma Chemical). Contents of TL and WE were given as $\mu \mathrm{g}$ ind..$^{-1}$.

After completion of lipid extraction the copepods were removed from the chloroform/methanol mixture, dried at $60^{\circ} \mathrm{C}$ to constant value and weighed on a balance to determine defatted dry weight (DFDW). Of the defatted individuals, 20 to 30 from stages CI to CIII and 3 to 5 (up to 10) ind. of each later stage were used for carbon content measuring with an EA 1110 CHNS analyser (CE Instruments).

Respiration rate was determined at $20^{\circ} \mathrm{C}$ in $\mathrm{CI}, \mathrm{CIV}$ and adults of Calanus euxinus from Stn 7 (after $1 \mathrm{~d}$ acclimation to $20^{\circ} \mathrm{C}$ ), and at $8^{\circ} \mathrm{C}$ in $\mathrm{CV}$ and female adults sampled near Sevastopol in April 2003. The data on respiration rates at $20^{\circ} \mathrm{C}$ of $\mathrm{C}$. euxinus from CII to adult females captured near Sevastopol in October 2002, September and October 2003 were used for the comparative analysis.

Respiration rate $\left(R, \mu g \mathrm{O}_{2}\right.$ ind..$\left.^{-1} \mathrm{~h}^{-1}\right)$ of copepods was determined using experimental and control syringes filled with $2.0 \mathrm{ml}$ of natural seawater. One adult female or CV (or 4 to 10 ind. CI to IV) was transferred by a pipette into each experimental syringe, which had a protective sieve disc (mesh size $200 \mu \mathrm{m}$ ) covering the outlet. To obtain identical initial oxygen and seston content in control and experimental syringes, we connected one of each with a plastic tube and pumped the water through them both simultaneously several times. Then the syringes were separated, closed by stoppers and placed in dark chambers at $20 \pm 0.5^{\circ} \mathrm{C}$ or $8 \pm 0.5^{\circ} \mathrm{C}$. Incubation periods were $1 \mathrm{~h}$ for adults and preadults and up to $2 \mathrm{~h}$ for CI to CII.

Oxygen concentration was measured using a polarographic membrane oxygen sensor OCE-057 (Marine Hydrophysical Institute, National Academy of Sciences of Ukraine) joined to a chamber (all-glass syringe), $0.5 \mathrm{ml}$ in volume and containing a magnetic stirrer (Svetlichny \& Hubareva 2005). The water sample from the experimental or control syringe was transferred through the needle to the chamber in 6 portions. A further 4 portions were used to calculate the average oxygen concentration.

Statistical evaluation of the data was conducted by 1-way ANOVAs. Values presented in figures and tables are means \pm SD. Relationships between any 2 variables were examined using least squares linear regression with Grapher ${ }^{\circledR}$ for Windows (v.2.00).

\section{RESULTS}

\section{Field observations}

In April 2003 the temperature of the aerobic layer was 6.8 to $8.5^{\circ} \mathrm{C}$ indicating a state of early spring homothermy in the Black Sea (Fig. 2). The lower boundary of the aerobic layer was located at $87 \mathrm{~m}$ in the cyclonic region (Stn 5) and 176 to $185 \mathrm{~m}$ in the anticyclonic regions (Stns 7 and 17). Oxygen-deficient waters with $<1 \mathrm{ml} \mathrm{O}_{2} \mathrm{l}^{-1}$ were deeper than 60 and 140 to $150 \mathrm{~m}$ in the cyclonic and anticyclonic regions, respectively. Fluorescence maxima were found at depths of $38 \mathrm{~m}$ (Stn 5) and 60 to $70 \mathrm{~m}$ (Stns 7 and 17). In these samples and within the OMZ we found a large number of alga Proboscia alata.

Total abundance of copepodites and adults of Calanus euxinus in the cyclonic zone region (Stn 5) was 14292 ind. $\mathrm{m}^{-2}$ and the biomass constituted $3.99 \mathrm{~g} \mathrm{~m}^{-2}$. In the anticyclonic regions their abundance amounted to 12202 and 13088 ind. $\mathrm{m}^{-2}$, or 5.7 and $7.3 \mathrm{~g} \mathrm{~m}^{-2}$ for Stns 7 and 17, respectively.

The age structures of Calanus euxinus populations in these 2 regions were different (Table 1). At Stn 5 early copepodite stages (CI to CIII) amounted to $76.1 \%$ of the total abundance (excluding nauplii). However, at Stns 7 and 17 preadults and adults (67.6 and $73.3 \%$ of the total abundance, respectively) predominated, with CV constituting 50 and $63 \%$, respectively. All early copepodite stages and the majority of preadults and adults were found above the OMZ at the anticyclonic Stn 17 both during the day- and nighttime. Within the OMZ at $11: 30 \mathrm{~h}$ only $3 \%$ of all CVs, $8 \%$ of all adult females and $63 \%$ of all adult males were found with their guts filled with green paste and $9.3 \%$ of all CVs had empty guts. All copepodites and adults collected at Stn 17 during the day-

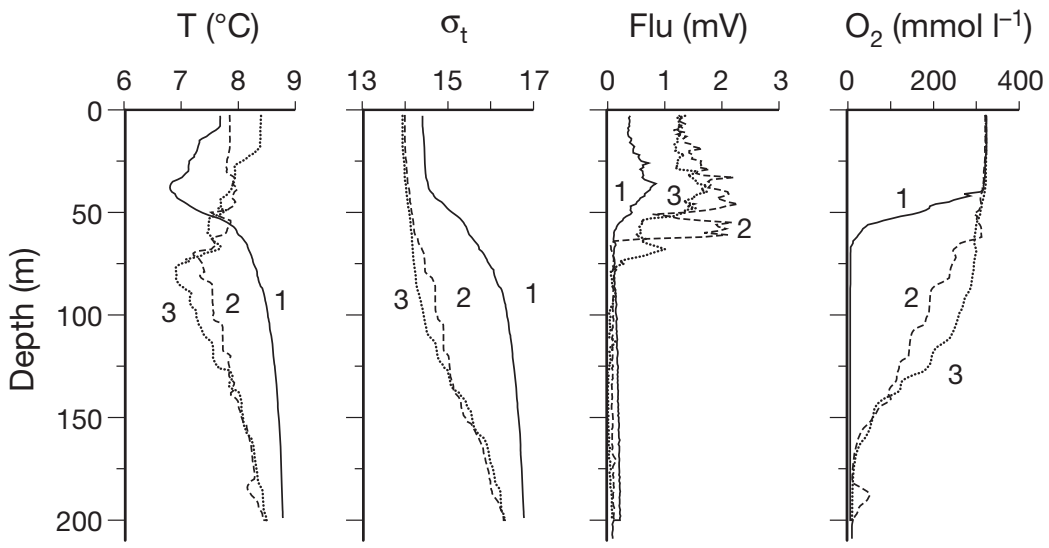

Fig. 2. Vertical profiles of temperature $\left(T,{ }^{\circ} \mathrm{C}\right)$, density $\left(\sigma_{t}\right)$, chl a in situ fluorescence $($ Flu, $\mathrm{mV})$ and oxygen concentration $\left(\mathrm{O}_{2}, \mathrm{mmol} \mathrm{l}^{-1}\right)$ from 1: cyclonic Stn 5 (17 April 2003), 2: anticyclonic Stns 7 (18 April 2003), and 3: 17 (22 April 2003) 
Table 1. Calanus euxinus. Abundance (No.; ind. $\mathrm{m}^{-2}$ ) and proportion (\% of total abundance) of copepodite stages (CI to CV), adult females (CVIF) and adult males (CVIM) in April 2003

\begin{tabular}{|c|c|c|c|c|c|c|c|c|c|c|c|c|}
\hline \multirow[t]{3}{*}{ Stage } & \multirow{2}{*}{\multicolumn{2}{|c|}{$\begin{array}{l}\text { Stn } 5 \\
90-0 \mathrm{~m} \\
01: 30 \mathrm{~h}\end{array}$}} & \multirow{2}{*}{\multicolumn{2}{|c|}{$\begin{array}{c}200-140 \mathrm{~m}, \\
18: 30 \mathrm{~h}\end{array}$}} & \multirow{2}{*}{\multicolumn{2}{|c|}{$\begin{array}{c}700-0 \mathrm{~m} \\
8: 50 \mathrm{~h}\end{array}$}} & \multirow{2}{*}{\multicolumn{2}{|c|}{$\begin{array}{c}190-0 \mathrm{~m} \\
22: 15 \mathrm{~h}\end{array}$}} & \multirow{2}{*}{\multicolumn{2}{|c|}{$\begin{array}{l}190-120 \mathrm{~m} \\
22: 30 \mathrm{~h}\end{array}$}} & & \\
\hline & & & & & & & & & & & \multicolumn{2}{|c|}{$\begin{array}{c}190-120 \mathrm{~m} \\
11: 30 \mathrm{~h}\end{array}$} \\
\hline & No. & $\%$ & No. & $\%$ & No. & $\%$ & No. & $\%$ & No. & $\%$ & No. & $\%$ \\
\hline CI & 3684 & 25.8 & 0 & 0 & 660 & 5.4 & 486 & 3.7 & 0 & 0 & 0 & 0 \\
\hline CII & 4048 & 28.3 & 0 & 0 & 1204 & 9.9 & 712 & 5.4 & 0 & 0 & 0 & 0 \\
\hline CIII & 3151 & 22.0 & 0 & 0 & 2096 & 17.2 & 2291 & 17.5 & 5 & 0.4 & 21 & 1.8 \\
\hline CIV & 1427 & 10.0 & 0 & 0 & 1934 & 15.9 & 1781 & 13.6 & 57 & 4.6 & 166 & 14.2 \\
\hline $\mathrm{CV}$ & 684 & 4.8 & 650 & 86.2 & 4157 & 34.1 & 6081 & 46.5 & 861 & 68.8 & 712 & 60.8 \\
\hline CVIF & 1113 & 7.8 & 57 & 7.6 & 1318 & 10.7 & 1482 & 11.3 & 166 & 13.3 & 112 & 9.5 \\
\hline CVIM & 185 & 1.3 & 47 & 6.2 & 832 & 6.8 & 255 & 2.0 & 161 & 12.9 & 161 & 13.7 \\
\hline
\end{tabular}

time between depths 0 to $60 \mathrm{~m}$ were found to have food in their guts.

For CIV all postmolts (PO + LPO), intermolts and all premolts (EPR $+\mathrm{PR})$ were found in similar proportions $(39,25$ and $36 \%$, respectively). However, among CIVs collected within the $\mathrm{OMZ}$, all premolts dominated (more than $90 \%$ of total number) (Fig. 3A). In contrast, POs and INs predominated among CVs found above and within the OMZ (Fig. 3B).

\section{Size-weight characteristics of Calanus euxinus}

In April $2003 L_{\mathrm{p}}$ ranged from $0.69 \pm 0.03 \mathrm{~mm}$ in CI to $2.65 \pm 0.09 \mathrm{~mm}$ in adult females and $2.53 \pm 0.1 \mathrm{~mm}$ in adult males. We did not find significant variation in $L_{\mathrm{p}}$ within the molting cycle of each copepodite stage at Stn 7 (Table 2). However, $V_{\mathrm{b}}$ increased by $28 \%$ ( $\mathrm{p}<$ 0.05) in CIII and CIV from POs to PRs and by $25 \%$ in CV from POs to INs (Fig. 4); increases were due to multiple (9.4 times in CIII, 50 times in CIV and close to 16 times in $\mathrm{CV}$ ) increments of oil sac volume $\left(V_{\mathrm{s}}\right)$ during the molting period of these stages. In $\mathrm{CV}$ we found significant $(\mathrm{p}<0.001)$ increases in DFDW from $63 \pm$ $3.5 \mathrm{mg}$ for POs to $127 \pm 3.2$ and $112 \pm 5.7 \mathrm{mg}$ for INs and PRs, respectively.

At $\operatorname{Stn} 7$, the frequency distribution of $V_{\mathrm{s}}$ in $\mathrm{CV}$ was bimodal above and within the $\mathrm{OMZ}$, with maxima at 0 to $4 \%$ and 18 to $26 \%$ of $V_{\mathrm{b}}$ (Fig. 5). CVs aggregating above the OMZ (85\% of CV total number) were mainly POs with small lipid sacs $\left(<8 \%\right.$ of $V_{\mathrm{b}}$ ) whilst about half of LPOs and the majority of INs and PRs contained oil sacs larger than $16 \%$ of $V_{\mathrm{b}}$.

CVs from the OMZ (15\% of CV total number) predominantly possessed large oil sacs. Among them the POs with empty guts (probably, diapausing individuals) were extremely lipid-rich (up to $30 \%$ of $V_{\mathrm{b}}$ ). Mean $V_{\mathrm{s}}$ in these CV POs $\left(0.151 \pm 0.039 \mathrm{~mm}^{3}\right)$ did not differ significantly from $V_{\mathrm{s}}$ in CV LPOs and INs (Table 2).

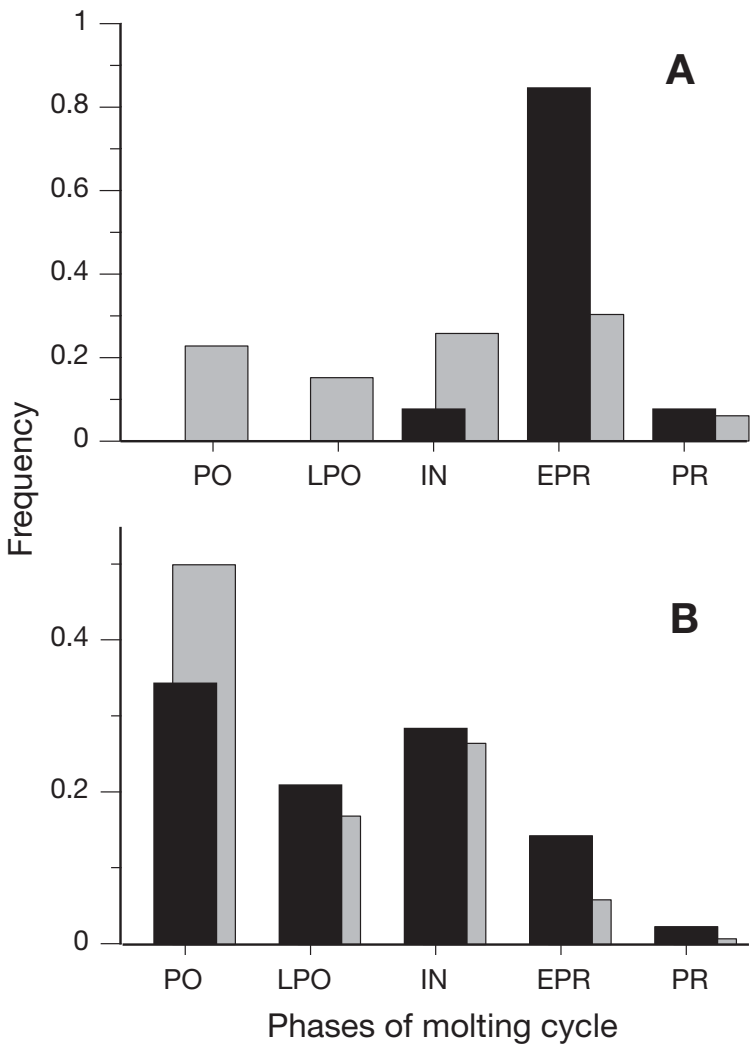

Fig. 3. Calanus euxinus. Jaw phase frequency distribution of copepodite stages: (A) CIV and (B) CV in total ( $\square$ )and within OMZ ( $\square$ ) hauls at Stns 7 (18 April 2003) and 17 (22 April 2003). PO: postmolt; LPO: late postmolt; IN: intermolt; EPR: early premolt; PR: premolt

Mean values of $V_{\mathrm{b}}$, DFDW and dry weight (DW, mg) determined as a sum of DFDW and TL in Calanus euxinus (Table 2), significantly ( $\mathrm{p}<0.001)$ correlated with $L_{\mathrm{p}}$ following the power equations $V_{\mathrm{b}}=0.057 L_{\mathrm{p}}{ }^{2.83}\left(\mathrm{r}^{2}=\right.$ 0.98), $\mathrm{DFDW}=0.0057 L_{\mathrm{p}}^{3.42}\left(\mathrm{r}^{2}=0.99\right)$ and $\mathrm{DW}=$ $0.0082 L_{\mathrm{p}}^{3.45}\left(\mathrm{r}^{2}=0.99\right)$, respectively. DFDW in CIs to adults increased proportionally with $V_{\mathrm{b}}$ as DFDW = 
Table 2. Calanus euxinus. Mean $\pm \mathrm{SD}$ values of prosome length $\left(L_{\mathrm{p}}, \mathrm{mm}\right)$, body volume $\left(V_{\mathrm{b}}, \mathrm{mm}^{3}\right)$, defatted dry weight (DFDW, $\left.\mu \mathrm{g}\right)$, carbon content as a percentage of defatted dry weight $(\mathrm{C}, \%)$, oil sac volume $\left(V_{\mathrm{s}}, \mathrm{mm}^{3}\right)$, total lipid content (TL, $\left.\mu g\right)$, wax ester content $(W E, \mu g)$ and dry weight (DW, $\mu \mathrm{g})$ in April 2003. F: females; M: males; PO: postmolt; POD: diapausing postmolt: LPO: late postmolt; IN: intermoult; EPR: early premolt; PR: premolt, n: number of individuals used for measuring $L_{\mathrm{p}}, V_{\mathrm{b}}$ and $V_{\mathrm{s}}$. Blank cells: no data

\begin{tabular}{|c|c|c|c|c|c|c|c|c|c|c|c|}
\hline Stn & Stage & Jaw phase & $\mathrm{n}$ & $L_{\mathrm{p}}$ & $V_{\mathrm{b}}$ & DFDW & $\mathrm{C}$ & $V_{\mathrm{s}}$ & $\mathrm{TL}$ & WE & DW \\
\hline \multirow[t]{3}{*}{5} & $\mathrm{CV}$ & All & 34 & $2.32 \pm 0.10$ & $0.626 \pm 0.116$ & 111.5 & & $92.9 \pm 74.3$ & 98.4 & 76.26 & 209.9 \\
\hline & CVIF & All & 24 & $2.62 \pm 0.09$ & $0.909 \pm 0.098$ & 153.3 & & $65.3 \pm 65.6$ & 49.7 & 32.84 & 203.0 \\
\hline & CVIM & All & 19 & $2.53 \pm 0.14$ & $0.827 \pm 0.138$ & 138.6 & & $100.7 \pm 62.6$ & 70.8 & 57.44 & 209.4 \\
\hline \multirow[t]{21}{*}{7} & $\mathrm{CI}$ & All & 16 & $0.69 \pm 0.03$ & $0.025 \pm 0.002$ & 1.5 & & 0 & 0.8 & 0 & 2.3 \\
\hline & CII & All & 20 & $0.95 \pm 0.04$ & $0.064 \pm 0.005$ & 5.1 & 51.7 & 0 & 2.4 & 0 & 7.5 \\
\hline & CIII & PO+LPO & 11 & $1.28 \pm 0.03$ & $0.093 \pm 0.008$ & & & $0.06 \pm 0.05$ & & & \\
\hline & & IN & 13 & $1.31 \pm 0.03$ & $0.103 \pm 0.015$ & & & $0.39 \pm 1.00$ & & & \\
\hline & & $\mathrm{EPR}+\mathrm{PR}$ & 9 & $1.35 \pm 0.06$ & $0.117 \pm 0.013$ & & & $0.55 \pm 0.41$ & & & \\
\hline & CIII & Total & 33 & $1.31 \pm 0.04$ & $0.103 \pm 0.012$ & $14.6 \pm 7.1$ & $37.9 \pm 9.3$ & $0.33 \pm 0.48$ & 3.2 & 0.96 & 17.8 \\
\hline & CIV & $\mathrm{PO}$ & 11 & $1.75 \pm 0.09$ & $0.215 \pm 0.030$ & & & $0.19 \pm 0.30$ & & & \\
\hline & & LPO & 8 & $1.78 \pm 0.08$ & $0.219 \pm 0.035$ & & & $0.29 \pm 0.22$ & & & \\
\hline & & IN & 12 & $1.78 \pm 0.05$ & $0.262 \pm 0.030$ & & & $5.30 \pm 3.60$ & & & \\
\hline & & EPR & 10 & $1.76 \pm 0.03$ & $0.293 \pm 0.030$ & & & $9.76 \pm 8.00$ & & & \\
\hline & & PR & 9 & $1.82 \pm 0,03$ & $0.275 \pm 0.013$ & & & $9.50 \pm 6.00$ & & & \\
\hline & CIV & All & 50 & $1.77 \pm 0.07$ & $0.245 \pm 0.038$ & $35.9 \pm 2.9$ & $34.9 \pm 1.0$ & $4.34 \pm 2.24$ & 9.8 & 5.40 & 45.7 \\
\hline & $\mathrm{CV}$ & $\mathrm{PO}$ & 67 & $2.26 \pm 0.06$ & $0.529 \pm 0.058$ & $63.0 \pm 3.5$ & $31.0 \pm 6.9$ & $8.00 \pm 7.00$ & & & \\
\hline & & POD & 18 & $2.36 \pm 0.10$ & $0.740 \pm 0.130$ & $106.0 \pm 11.4$ & $43.3 \pm 1.8$ & $151.0 \pm 39.0$ & 172.0 & 129.79 & 278.0 \\
\hline & & LPO & 29 & $2.29 \pm 0.08$ & $0.641 \pm 0.110$ & & & $122.0 \pm 64.0$ & & & \\
\hline & & IN & 45 & $2.33 \pm 0.11$ & $0.714 \pm 0.108$ & $127.3 \pm 3.2$ & $42.7 \pm 0.4$ & $165.0 \pm 54.0$ & & & \\
\hline & & EPR & 19 & $2.28 \pm 0.10$ & $0.653 \pm 0.120$ & $112.8 \pm 5.7$ & $41.5 \pm 0.7$ & $126.0 \pm 40.0$ & & & \\
\hline & & PR & 9 & $2.21 \pm 0.17$ & $0.660 \pm 0.160$ & & & $120.0 \pm 53.0$ & & & \\
\hline & $\mathrm{CV}$ & All & 187 & $2.30 \pm 0.09$ & $0.652 \pm 0.122$ & $90.8 \pm 9.0$ & $41.9 \pm 8.1$ & $92.0 \pm 79.0$ & 50.6 & 38.42 & 141.4 \\
\hline & CVIF & All & 28 & $2.67 \pm 0.06$ & $0.953 \pm 0.110$ & 147.7 & $42.9 \pm 0.5$ & $65.0 \pm 46.0$ & 56.8 & 38.76 & 204.5 \\
\hline & CVIM & All & 13 & $2.52 \pm 0.08$ & $0.776 \pm 0.093$ & 129.4 & $53.2 \pm 5.9$ & $95.0 \pm 60.0$ & 83.4 & 64.40 & 212.8 \\
\hline \multirow[t]{4}{*}{17} & $\mathrm{CV}$ & All & 44 & $2.29 \pm 0.11$ & $0.603 \pm 0.128$ & 102.9 & & $81.5 \pm 75.8$ & 76.2 & 60.96 & 179.1 \\
\hline & & POD & 14 & $2.25 \pm 0.10$ & $0.641 \pm 0.127$ & 107.1 & & $116.8 \pm 66.6$ & 142.9 & 111.90 & 250.0 \\
\hline & CVIF & All & 29 & $2.67 \pm 0.10$ & $0.950 \pm 0.152$ & 164.1 & & $43.5 \pm 50.8$ & 44.2 & 29.02 & 208.3 \\
\hline & CVIM & All & 17 & $2.53 \pm 0.08$ & $0.820 \pm 0.016$ & 122.0 & & $131.8 \pm 95.2$ & 91.7 & 77.85 & 213.7 \\
\hline
\end{tabular}

$-0.0063+0.17 V_{\mathrm{b}}\left(\mathrm{r}^{2}=0.97\right)$. In diapausing CV POs DFDW was 1.7 higher than that of CV just after ecdysis indicating that lipid accumulation in POs was accompanied by somatic growth.

Mean values of TL and WE correlated with $V_{\mathrm{s}}$ (Fig. 6) as $\mathrm{TL}=0.00503+0.83 V_{\mathrm{s}}\left(\mathrm{r}^{2}=0.99\right)$ and $\mathrm{WE}=0.00087+$ $0.58 V_{\mathrm{s}}\left(\mathrm{r}^{2}=0.99\right)$ in CIII to CV with $V_{\mathrm{s}}<0.065 \mathrm{~mm}^{3}$ whilst in CVs and adults with $V_{\mathrm{s}}>0.065 \mathrm{~mm}^{3} \mathrm{TL}=$ $-0.0271+1.32 V_{\mathrm{S}}\left(\mathrm{r}^{2}=0.95\right)$ and $\mathrm{WE}=-0.0264+1.062$ $V_{\mathrm{s}}\left(\mathrm{r}^{2}=0.94\right)$.

\section{Respiration rate}

Respiration rate $\left(\mathrm{R}, \mu \mathrm{g} \mathrm{O} \mathrm{O}_{2}\right.$ ind. $\left.{ }^{-1} \mathrm{~h}^{-1}\right)$ was determined in Calanus euxinus from CI to adult females collected in the southeastern Black Sea in April 2003 during shipboard experiments at $20^{\circ} \mathrm{C}$ and in the laboratory at $8^{\circ} \mathrm{C}$ in $\mathrm{CV}$ and adult females collected near Sevastopol. Also, we studied respiration rate in C. euxinus copepodites and females sampled in October 2002 and in
September to October 2003 near Sevastopol at $20^{\circ} \mathrm{C}$. Before the experiments individuals were kept for $1 \mathrm{~d}$ in seawater with a mixture of algae Prorocentrum micans and Thalassiosira weisflogii at the given temperature for acclimation.

We analyzed only the results of those experiments in which copepods performed high activity. Within the WW range of 0.03 to $1.27 \mathrm{mg}$ at $20^{\circ} \mathrm{C}$, respiration rate increased from 0.052 in CI to $2.13 \mu \mathrm{g} \mathrm{O}_{2}$ ind. $^{-1} \mathrm{~h}^{-1}$ in adult females. Since the results obtained during spring and autumn experiments were similar (Fig. 7), we expressed the relationship between respiration rate and body weight at $20^{\circ} \mathrm{C}$ by a single power equation $\mathrm{R}=1.61 \mathrm{WW}^{1.01}\left(\mathrm{r}^{2}=0.99\right)$. Respiration rate in CVs and adult females at $8^{\circ} \mathrm{C}$ was 2.7 times lower than that in individuals with similar WW at $20^{\circ} \mathrm{C}$. Respiration rate at $8^{\circ} \mathrm{C}$ was described by the equation $\mathrm{R}=0.69 \mathrm{WW}^{1.05}$. The mean $Q_{10}$ in the temperature range of 8 to $20^{\circ} \mathrm{C}$ for Calanus euxinus individuals with the same body size was equal to $2.04 \pm 0.02$. Similar $Q_{10}$ values were obtained by Vidal (1980c) and Ikeda et al. (2001). 

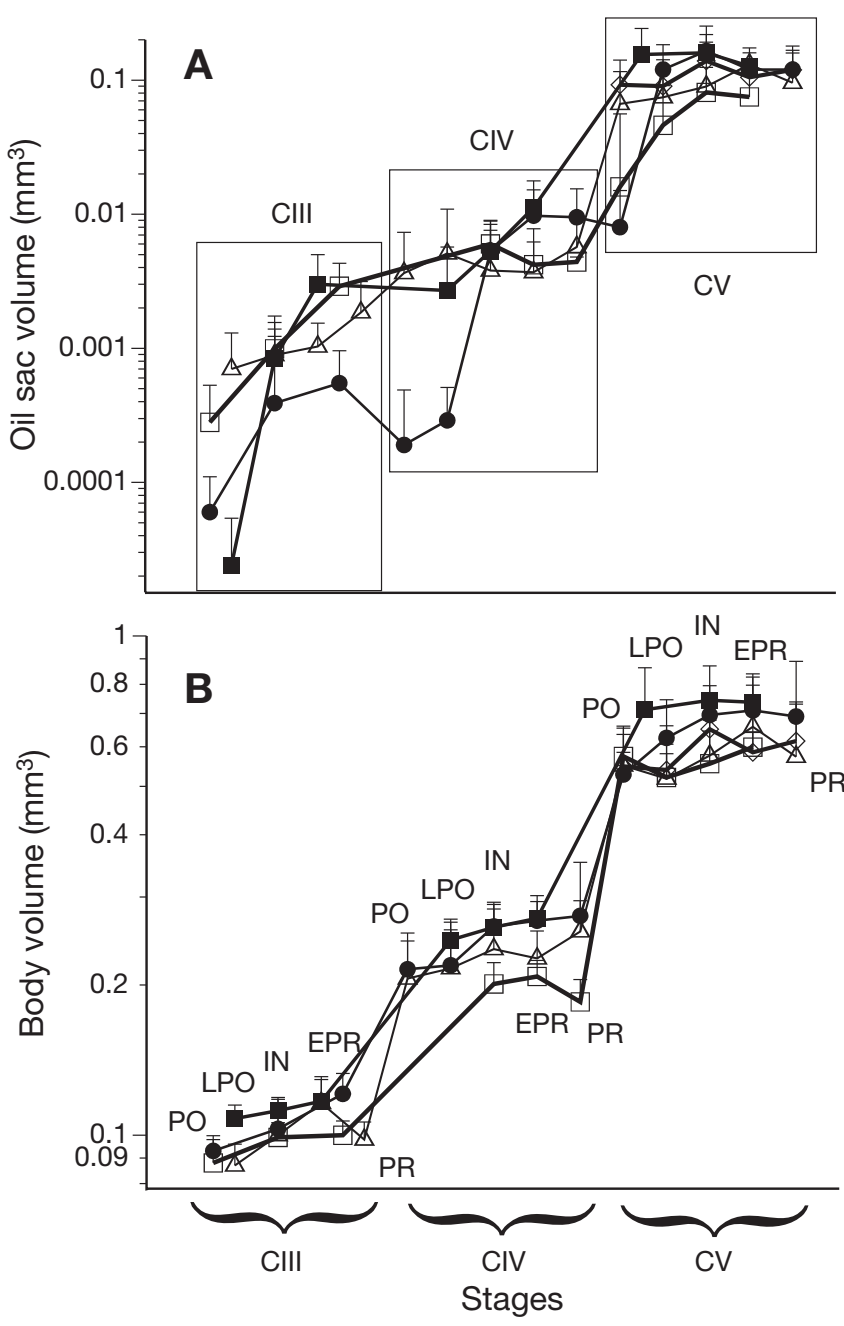

Fig. 4. Calanus euxinus. (A) Oil sac and (B) body volume of copepodite stages CIII to CV at different jaw phases in February $(\square)$ and September $(\diamond)$ 1999, July $2000(\Delta)$, June $2001(\square)$ and April 2003 (๑). PO: postmolt; LPO: late postmolt; IN: intermolt; EPR: early premolt; PR: premolt

\section{DISCUSSION}

\section{Population structure of Calanus euxinus}

Usually, late copepodite stages and adults of Calanus euxinus are abundant predominantly in deep shelf or slope regions in the main stream of the Black Sea Rim Current whilst towards the coast the number of early developmental stages increases (Vinogradov et al. 1992b). In contrast in April 2003 a large number of early copepodite stages of $C$. euxinus (10 883 ind. $\mathrm{m}^{-2}$ ) were found in the central part of the Black Sea (Stn 5). At slope Stns 7 and 17, where preadults and adults predominated, total biomass amounted to $7.3 \mathrm{~g} \mathrm{~m}^{-2}$. Similar and even higher values of biomass (up to $23.6 \mathrm{~g}$ $\mathrm{m}^{-2}$ ) of $C$. euxinus were reported for the northeastern
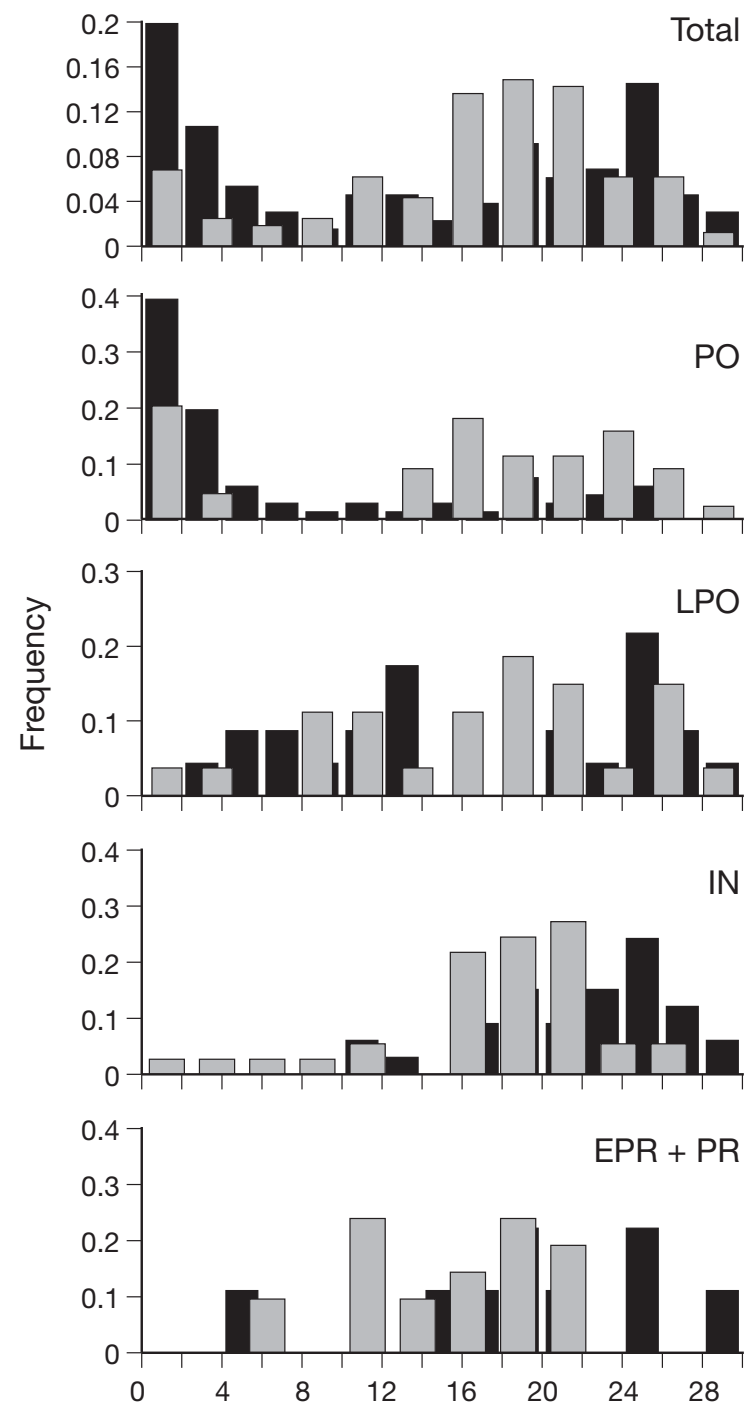

Specific oil sac volume (\% of body volume)

Fig. 5. Calanus euxinus. Oil sac volume frequency distribution in $\mathrm{CV}$ at different jaw phases from the total ( $\square$ ) and within OMZ (ם) hauls at Stn 7 (18 April 2003). PO: postmolt; LPO: late postmolt; IN: intermolt; EPR: early premolt; PR: premolt

deep region of the Black Sea in August to September 2001 to 2004 (Vinogradov et al. 2005) and June to September 2005 (Vinogradov et al. 2006) during the phytoplankton depression period. High biomass of $C$. euxinus (up to $5.5 \mathrm{~g} \mathrm{~m}^{-2}$ ) was also found in the southwestern Black Sea in summer (Vinogradov et al. 1995), autumn (Yuneva et al. 1999, Besiktepe \& Unsal 2000, Svetlichny et al. 2006) and during the phytoplankton rich winter-spring period (Vinogradov et al. 1992c).

However, local densities of Calanus euxinus population in the Black Sea may be even higher, because preadults and adults usually ascend to subsurface layers at night and aggregate in the OMZ during daytime 


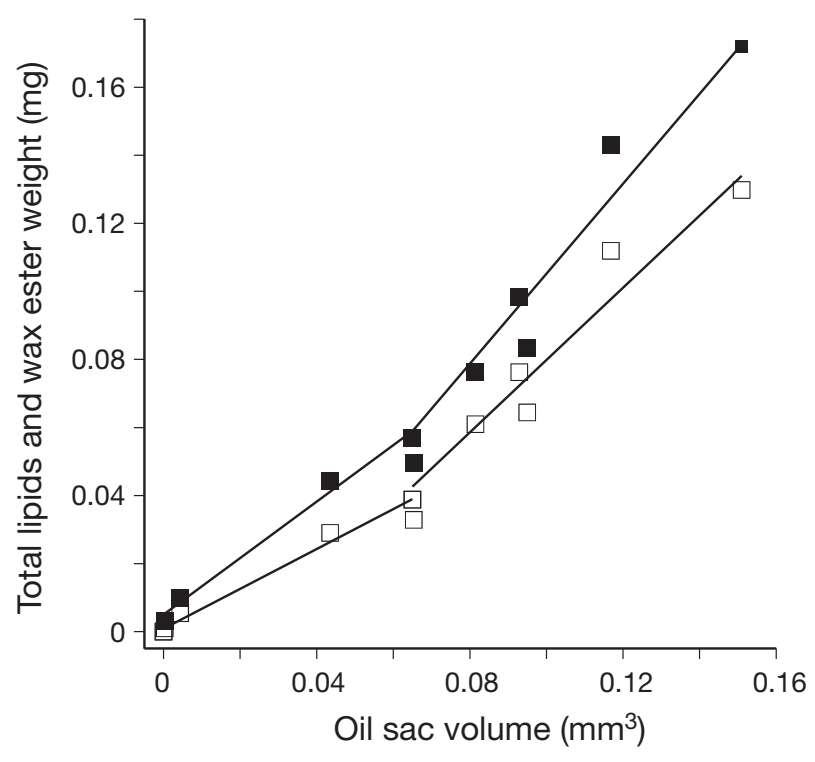

Fig. 6. Calanus euxinus. Total lipid ( $\square$ ) and wax ester ( $\square$ ) contents versus oil sac volume in copepodite stages

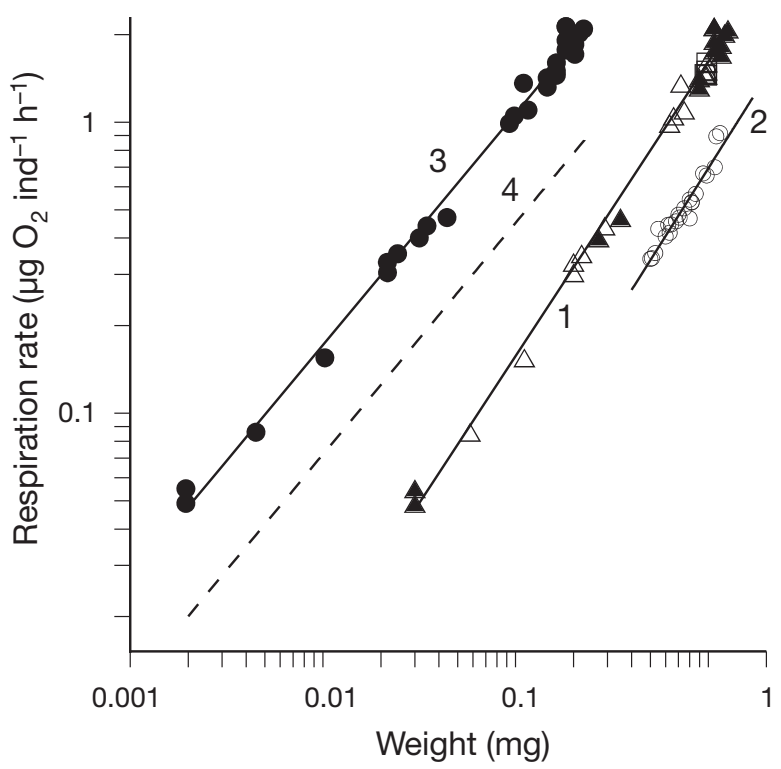

Fig. 7. Calanus euxinus. Relationships between respiration

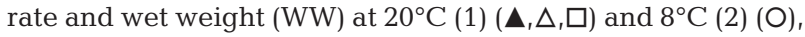
and between respiration rate and defatted dry weight at $20^{\circ} \mathrm{C}$

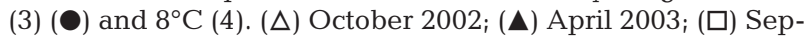
tember to October 2003. Regression of respiration rate at $8^{\circ} \mathrm{C}$ against DW (4) was calculated on the basis of the relationship between respiration rate at $20^{\circ} \mathrm{C}$ and $\mathrm{WW}$ taking into account age changes in the WW:DW ratio

(Besiktepe 2001). Vinogradov et al. (1992a,c) reported on C. euxinus daytime aggregations with biomass $1.1 \mathrm{~g}$ $\mathrm{m}^{-3}$ in February 1991 and up to $3.5 \mathrm{~g} \mathrm{~m}^{-3}$ in April 1988.

Such high population densities in the closely related Calanus helgolandicus were found only in waters sur- rounding the western Iberian Peninsula and in the North Adriatic (Bonnet et al. 2005). C. euxinus was found to be abundant during all seasons (Sazhina 1987) and over the whole open part of the Black Sea (Vinogradov et al. 1992b) whilst in the other seas of the North Atlantic Calanus development strongly depends upon seasonal changes in phytoplankton concentration (Ceballos et al. 2004, Rey-Rassat et al. 2004).

During all seasons late development stages of Calanus euxinus migrate in the morning to the OMZ where they reduce respiration rate and stop feeding (Vinogradov et al. 1992a,b). CV and adults began to feed again during the night and ascend to the upper layers (Besiktepe et al. 2005). According to our observations, in autumn 1996 and 1998 and in summer 2000 and 2001 (L. Svetlichny unpubl. data) the guts of CV and adults $C$. euxinus were empty or contained small dark lumps during daytime. But in April at the anticyclonic Stn 17 the majority of preadults and adults were above the OMZ and had food in their guts during both dayand nighttime. This may be due to a high concentration of Proboscia alata in deep layers which allows C. euxinus to feed all day long without vertical migration. Eker-Develi \& Kideys (2003) also found that in March to April 1998, P. alata aggregated far below the euphotic zone (56 to $86 \mathrm{~m}$ ). Probably, the huge amount of large diatoms outside the euphotic zone is due to sinking of algae after the winter-spring phytoplankton bloom.

Only 8 to $9 \%$ of $\mathrm{CV}$ sampled within the OMZ had empty guts and large oil sacs suggesting that diapausing stock began to form just in this period. According to Vinogradov et al. (1992a) and Svetlichny et al. (1998, 2006), CV POs with empty guts and large oil sacs captured in the OMZ at night, had reduced respiration and nitrogen excretion rates, low locomotor activity and were considered as diapausing copepodites. C. euxinus CV in 'resting phase' with low locomotor activity have been observed in the OMZ (Flint 1989). According to Vinogradov et al. (1992b), diapausing $\mathrm{CV}$ appeared in low numbers in the Black Sea in April to May. In summer their numbers increased and constituted on average $30 \%$ (up to $70 \%$ ) of the CV total number in autumn. However, in winter diapausing CV were absent.

Therefore, it appears that CV moulting phases LPO, IN and PR collected in April 2003 developed from POs without entering diapause.

The great number of CIV PRs (especially in the OMZ) is evidence of favorable nutritional conditions for Calanus euxinus in April (Fig. 3A). Crain \& Miller (2001) showed that under conditions of experimental starvation the suppression of development took place in CII to CIV POs. However, C. euxinus CV POs dominated even at high food concentrations due to the long- 
drawn process of lipid accumulation during this stage (Svetlichny et al. 2006). Therefore, the predominance of PO jaw phase could be found not only in CVs preparing to diapause (Johnson 2004), but in CVs developing without diapause. In April 2003, POs dominated CV with a small percentage of INs and PRs in the layers above and within the OMZ (Fig. 3B), in contrast to summer and autumn (Svetlichny et al. 2006) when only diapausing POs stayed in the OMZ at night.

\section{Ontogenetic changes in size-weight characteristics of Calanus euxinus}

According to our results, in Calanus euxinus $L_{\mathrm{p}}$ increased with higher increments in CIII to $\mathrm{CV}$ and with lower increments from $\mathrm{CI}$ to $\mathrm{CIII}$ and from $\mathrm{CV}$ to adults. Similar sigmoidal development has been described for C. marshallae (Peterson 1986). We did not find significant differences in $L_{\mathrm{p}}$ of copepodites and adults collected in April 2003, from mean annual values obtained in the southern and southwestern Black Sea during 1999 to 2003, despite the pronounced seasonal changes in surface temperature (Fig. 8). During the warm period from June to October mean $L_{\mathrm{p}}$ of C. euxinus females $(2.63 \pm 0.12 \mathrm{~mm})$ did not differ significantly from that in cold months from January to April $(2.66 \pm 0.09 \mathrm{~mm})$. This may be the result of C. euxinus development in the Rim Current zone of the Black Sea, in the deep layers with low and stable temperatures $\left(6.5\right.$ to $\left.8.5^{\circ} \mathrm{C}\right)$ throughout the year. According to Bonnet et al. (2005), in European waters the size of $C$. helgolandicus female $L_{\mathrm{p}}$ changes from 1.94 in the Aegean Sea to $2.6 \mathrm{~mm}$ in the North Sea. Fleminger \& Hulsemann (1987) reported that within the geographical range of $C$. helgolandicus the Black Sea females have maximum body size, probably, due to the hydrochemical characteristics of the Black Sea.

In April 2003 mean DW in Calanus euxinus increased proportionally with $L_{\mathrm{p}}$ following the power equation DW $=0.0082 L_{\mathrm{p}}{ }^{3.45}$. Besiktepe \& Telli (2004) found similar age dynamics of DW in C. euxinus in October 2000 $\left(\mathrm{DW}=0.0069 L_{\mathrm{p}}{ }^{3.41}\right)$ and May $2001\left(\mathrm{DW}=0.0062 L_{\mathrm{p}}{ }^{3.34}\right)$.

The regression for DW against $L_{\mathrm{p}}$ has a steeper slope (3.45) than that for $V_{\mathrm{b}}$ against $L_{\mathrm{p}}(2.83)$, indicating that during Calanus euxinus ontogeny DW increased with lower speed than $V_{\mathrm{b}}$ resulting in reduced water content ( $\%$ of $V_{\mathrm{b}}$ ) in preadults and adults. DFDW per unit volume increased uniformly from $0.06 \mathrm{mg} \mathrm{mm}^{-3}$ in CI to $0.15 \mathrm{mg} \mathrm{mm}^{-3}$ in adults, DW per unit volume rose from $0.092 \mathrm{mg} \mathrm{mm}^{-3}$ in CI to $0.38 \mathrm{mg} \mathrm{mm}^{-3}$ in CV and then reduced to $0.21 \mathrm{mg} \mathrm{mm}^{-3}$ in females and $0.27 \mathrm{mg}$ $\mathrm{mm}^{-3}$ in males. Similar DW content have been reported for $\mathrm{CV}$ and adults of $C$. helgolandicus from the Celtic Sea (Williams \& Robins 1982).
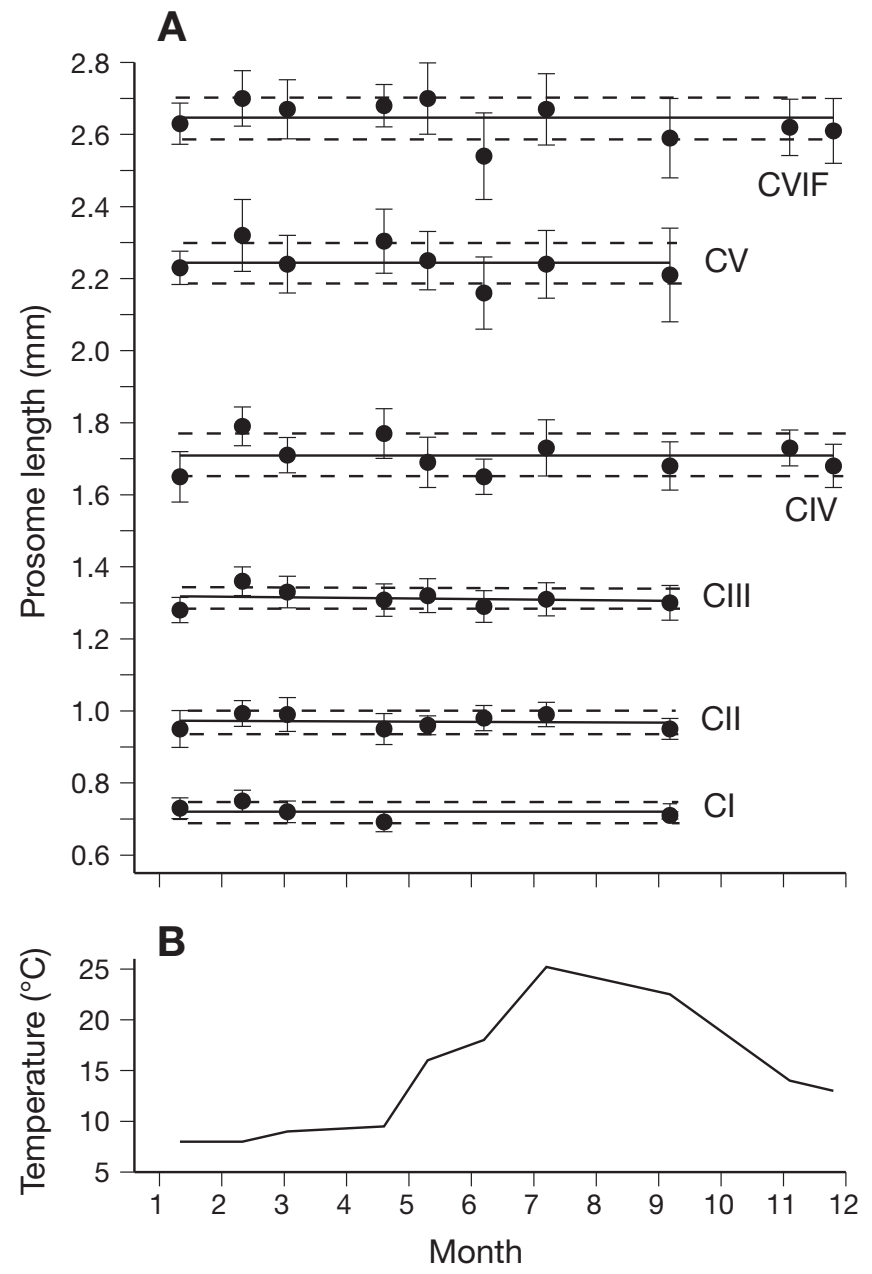

Fig. 8. Calanus euxinus. (A) Prosome length of copepodites (CI to CV) and adult females (CVIF) from the southwestern Black Sea (April 2003, June 2001 and July 2000) and from the southern Black Sea (off Sinop, 1999, all other months), and (B) surface water temperature during sampling. Solid line = mean annual values; dashed line $=\mathrm{SD}$

Calanus euxinus accumulate lipids in the oil sac mainly in the form of WEs (Yuneva et all. 1997). However, if we transform $V_{\mathrm{s}}$ to weight of WE with the density of $0.86 \mathrm{~g} \mathrm{~mm}^{-3}$ (Lewis 1970), WE estimated from $V_{\mathrm{s}}$ in $\mathrm{CV}$ and females will be $1.23 \pm 0.26$ times higher than measured WE (see Table 2). According to Miller et al. (1998), in C. finmarchicus the ratio between estimated (from the oil sac volume) and measured WE was equal to 1.44. However, the oil sac of $C$. euxinus contains about $9 \%$ of other lipid fractions (probably, the components of oil sac cell membranes) (T. Yuneva pers. comm.). Therefore, the overestimation of lipid amount in the oil sac using the volume method will be nearly $10 \%$. In Calanoides carinatus $V_{\mathrm{s}}$ in terms of weight units also was close to measured amount of reserved lipids (Arashkevich et al. 1996). 


\section{Variability in lipid reserves during the phases of $\mathrm{CV}$ molting cycle}

In April 2003 mean $V_{\mathrm{s}}$ increased from $0.008 \pm$ $0.007 \mathrm{~mm}^{3}$ in POs to $0.109 \pm 0.066 \mathrm{~mm}^{3}$ in LPOs and reached $0.165 \pm 0.054 \mathrm{~mm}^{3}$ in CV INs (Table 2). Consequently, during the $\mathrm{PO}$ period $V_{\mathrm{s}}$ in Calanus euxinus increased nearly 14-fold. However, the difference between mean values in all examined LPOs and INs was found to be insignificant because $V_{\mathrm{s}}$ in both molting stages ranged from zero to the maximum (Fig. 5).

Miller et al. (2000) showed that despite high variability of $V_{\mathrm{s}}$ its upper limit in Calanus finmarchicus CV ('apparent maximum' represented by an approximate upper envelope that lies above $98.5 \%$ of the data points) increased with body size. In our study we determined the upper limit of $V_{\mathrm{s}}\left(V_{\mathrm{ul}}\right)$ as mean $V_{\mathrm{s}}$ estimated using 10 extremely lipid-rich individuals. As a result, $V_{\mathrm{ul}}$ in LPOs $\left(0.173 \pm 0.021 \mathrm{~mm}^{3}\right)$ was significantly lower than that in INs $\left(0.226 \pm 0.04 \mathrm{~mm}^{3}\right)$. A similar $V_{\mathrm{ul}}$ $\left(0.208 \pm 0.05 \mathrm{~mm}^{3}\right)$ was found in February 1999 also in INs. In autumn 1998 and during summer phytoplankton depression in 2000 and $2001 V_{\mathrm{ul}}$ in CV INs amounted to $0.139 \pm 0.016 \mathrm{~mm}^{3}$ and $0.119 \pm 0.026 \mathrm{~mm}^{3}$, respectively, being lower than those in winter and spring.

In February and April $V_{\mathrm{s}}$ CIV INs were larger than those collected in the warm period. During the cold season we observed maximum $V_{\mathrm{b}}$ in all copepodite stages (Fig. 4B). This may be connected with better nutritional conditions for Black Sea Calanus during the winter-spring period. However, in summer the amount of lipid reserves was also higher in C. euxinus than in $C$. helgolandicus from the English Channel (Rey-Rassat et al. 2002a) but similar to that in C. finmarchicus (with similar body size) from the North Atlantic (Miller et al. 2000) and the North Sea (ReyRassat et al. 2002b).

\section{Age dynamics of respiration rate}

According of our results, WW dependent changes in Calanus euxinus respiration rate during the ontogeny from $\mathrm{CI}$ to CVI can be expressed by the equations $R=$ $1.61 \mathrm{WW}^{1.01}$ and $R=0.69 \mathrm{WW}^{1.05}$ at $20^{\circ} \mathrm{C}$ and $8^{\circ} \mathrm{C}$, respectively (Fig. 7). The slopes in these regressions are higher than the exponent values for dry body mass of about 0.8 reported on oxygen consumption rates of planktonic copepods (Vidal 1980c, Ikeda et al. 2001). However, if we change the body weight units from WW to DFDW (which reflects the amount of metabolically active matter in the body), the above equations become $R=6.69 \mathrm{DFDW}^{0.8}$ and $R=2.84 \mathrm{DFDW}^{0.8}$ for $20^{\circ} \mathrm{C}$ and $8{ }^{\circ} \mathrm{C}$ respectively. This is due to a lower share of DFDW in early copepodite stages compared with preadults and adults in C. euxinus.

In April 2003 weight-specific respiration rate in active females with a DW of $0.267 \mathrm{mg}$ at $20^{\circ} \mathrm{C}$ reached $2.13 \mu \mathrm{g} \mathrm{O}_{2}$ ind. $^{-1} \mathrm{~h}^{-1}$ or $7.9 \mu \mathrm{g} \mathrm{O}_{2} \mathrm{mg} \mathrm{DW}^{-1} \mathrm{~h}^{-1}(18.5 \mu \mathrm{g}$ $\mathrm{O}_{2} \mathrm{mg} \mathrm{C}^{-1} \mathrm{~h}^{-1}$ ), being close to maximum energy expenditure in Calanus euxinus females during permanent swimming at the same temperature (Pavlova \& Minkina 1987, Svetlichny \& Hubareva 2005). According to the equation of Ikeda et al. (2001), in epipelagic copepods with the same body weight at $20^{\circ} \mathrm{C}$ weightspecific respiration rate amounted to $4.96 \mu \mathrm{g} \mathrm{O} \mathrm{O}_{2} \mathrm{mg}$ $\mathrm{DW}^{-1} \mathrm{~h}^{-1}$. After using the equation of Vidal (1980c) for C. pacificus at $20^{\circ} \mathrm{C}$, we estimated weight-specific respiration rate in $C$. euxinus females as $8.86 \mu \mathrm{g} \mathrm{O}_{2} \mathrm{mg}$ $\mathrm{DW}^{-1} \mathrm{~h}^{-1}$.

At $8^{\circ} \mathrm{C}$, weight-specific respiration rate of Calanus euxinus females was $3.43 \mu \mathrm{g} \mathrm{O} \mathrm{O}_{2} \mathrm{DW}^{-1} \mathrm{~h}^{-1}$ and, according to Vidal (1980c), was $30 \%$ lower than that of C. pacificus (4.95 $\mu \mathrm{g} \mathrm{O}_{2} \mathrm{mg} \mathrm{DW}^{-1} \mathrm{~h}^{-1}$ ). This difference may be due to the lower salinity of the Black Sea. For example, Anraku (1964) found more than a 2-fold decrease in respiration rate of $C$. finmarchicus during salinity reduction from 31.5 to $21.5 \%$. In our experiments (L. Svetlichny \& E. Hubareva unpubl. data) weight-specific respiration rate of $C$. euxinus reared at $39 \%$ was significantly 1.3 times higher than that at the Black Sea salinity of 18 to $20 \%$.

\section{Reconstruction of growth in body weight and estimation of stage duration}

Although Calanus euxinus copepodites and adults collected in April 2003 do not represent a temporal progression of successive stages in cohort, we can reconstruct age dynamics of DW during the winterspring period using our findings that $V_{\mathrm{s}}, V_{\mathrm{b}}$ (Fig. 4) and molt increments of $L_{\mathrm{p}}$ (Fig. 8) are similar in winter and spring. The weight of body compartments may be expressed in terms of carbon taking into account the ratio of the carbon content as 0.81 for WE, 0.78 for TL containing 70 to $72 \%$ of WE, 8 to $13 \%$ of triacylglycerols, 13 to $15 \%$ of phospholipids and 3 to $5 \%$ of sterols (Yuneva et al. 1999), according to stoichiometric composition of the main lipid compounds in calanoid copepods (Ventura 2006), and as $0.42 \pm 0.6$ for DFDW (our data, Table 2). Our calculations were based on the results of direct measurements (Table 2). Because of absence of the data on single molting copepodite phases, we used the empiric relations of WE and TL to $V_{\text {s }}$ obtained in our study (Fig. 6). Total carbon weight was determined as a sum of carbon contents in DFDW and TL. Reconstruction of age dynamics of weight compartments in CI through adult females is shown in 
Fig. 9. Calculated mean total carbon content increased uniformly from $1.3 \mu \mathrm{g}$ in CI to $28 \mu \mathrm{g}$ in CIV PRs, changed from 44 to $147 \mu \mathrm{g}$ during the CV PO phase, reached $205 \mu \mathrm{g}$ in the $\mathrm{CV}$ interphase and then decreased to $115 \mu \mathrm{g}$ in adult females. In CIII to CV carbon content of TL and WE tended to increase during molting periods and then reduced after ecdysis. This is connected with energy expenditure during ecdysis which may result in losses of $22 \%$ of carbon weight (Rey-Rassat et al. 2002b). In females, pronounced lipid depletion is due to gonad formation and egg production (Sargent \& Henderson 1986). In contrast to TL and WE, DFDW does not vary greatly within a single development stage. Carbon content of DFDW increased nearly uniformly from $0.65 \mu \mathrm{g}$ in CI to $67 \mu \mathrm{g}$ in adult females.

Using our results concerning age dynamics of body weight and available literature data on growth rates in Calanus, we can estimate stage duration and total generation time of $C$. euxinus during winter-spring homothermy. Sazhina (1987) found that in a laboratory experiment at $18^{\circ} \mathrm{C}$, development time (from egg to adult) of Black Sea Calanus amounted to $34 \mathrm{~d}$. Stage durations amounted to $3 \mathrm{~d}$ for $\mathrm{CI}$ and CII, $4 \mathrm{~d}$ for CIII, $5 \mathrm{~d}$ for CIV and CV. However, there is no information available for growth of this species in the natural environment at $8^{\circ} \mathrm{C}$. Therefore, to estimate the duration of copepodite development in Calanus euxinus during winter-spring homothermy at $8^{\circ} \mathrm{C}$, we calculated time dependent changes in carbon body weight (CW) of $\mathrm{CI}$ $(1.3 \mu \mathrm{g} \mathrm{C})$ through CV INs $(205 \mu \mathrm{g} \mathrm{C})$ according to the equation: $\mathrm{CW}_{t}=\mathrm{CW}_{t-1}+P_{t-1}$, where $t$ is time $\left(\mathrm{d}^{-1}\right)$ and $P$ is absolute growth rate $\left(\mathrm{mg} \mathrm{C}\right.$ ind.$^{-1} \mathrm{~d}^{-1}$ ).

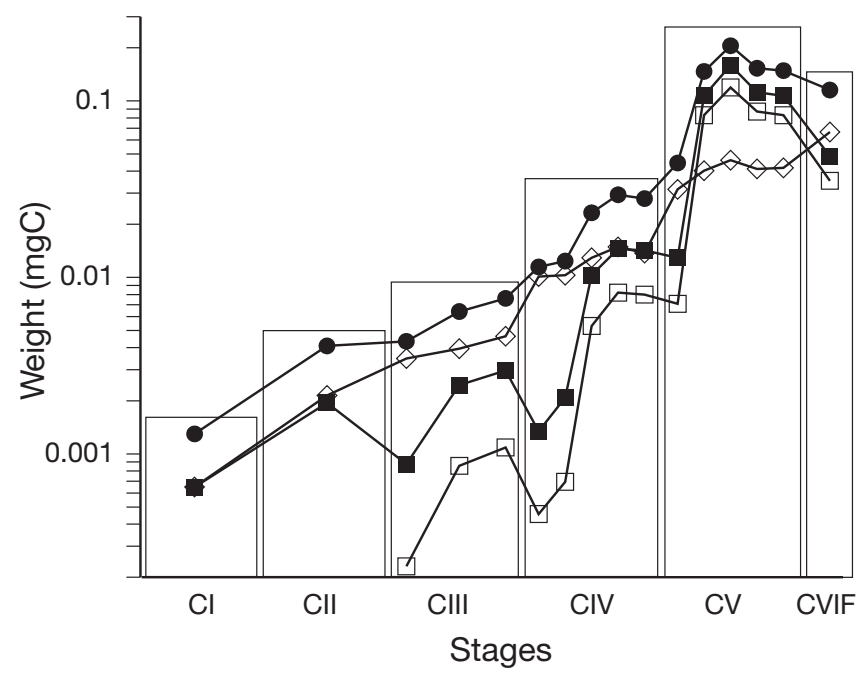

Fig. 9. Calanus euxinus. Age dynamics of total carbon content $(\bullet)$ and carbon equivalents of defatted dry weight $(\diamond)$, total lipids ( $\square$ ) and wet weight ( $\square$ ) in copepodites CI to adult females (CVIF)
$P$ was calculated based on ontogenetic changes in specific growth rate $\left(g, \mathrm{~d}^{-1}\right)$ of Calanus finmarchicus copepodites with similar body size and carbon content, reared at $8^{\circ} \mathrm{C}$ under non-limiting food concentration (Campbell et al. 2001, their Table 5). For CI to CV of this species $g$ decreased from 0.31 to $0.042 \mathrm{~d}^{-1}$ (Fig. 10A). Similar dynamics of $g$ was found in C. sinicus with smaller body length at $8^{\circ} \mathrm{C}$ (Uye 1988). Vidal (1980a) estimated $g$ as $0.118 \mathrm{~d}^{-1}$ for C. pacificus CV. However, this value may be considered to be overesti-
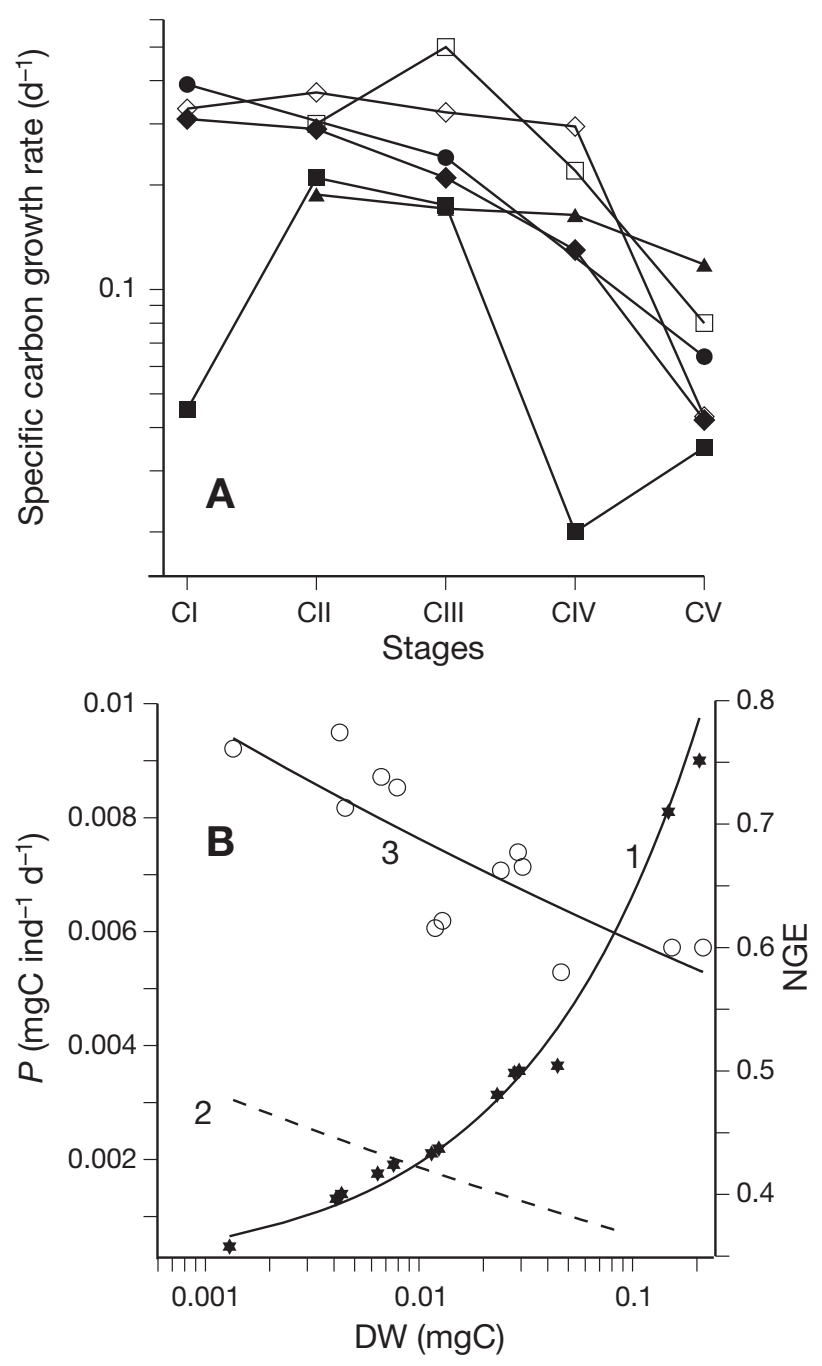

Fig. 10. Age dynamics of (A) specific carbon growth rate $\left(\mathrm{d}^{-1}\right)$ in Calanus group species, and (B) absolute growth rate $(P$, mgC ind.$^{-1} \mathrm{~d}^{-1}$ ) and net growth efficiency (NGE) in C. euxinus copepodites. Growth rates in sibling Calanus species at high

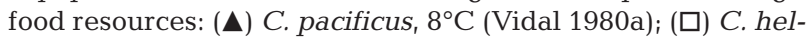
golandicus, $15^{\circ} \mathrm{C}$ (Harris et al. 2000); (•) C. sinicus, $8^{\circ} \mathrm{C}$ (Uye

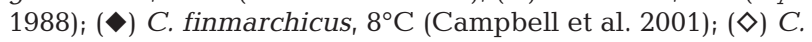
helgolandicus, $15^{\circ} \mathrm{C}$ (Rey-Rassat et al. 2002a); (ם) C. finmarchicus, $10^{\circ} \mathrm{C}$ (Harris et al. 2000). $(1, *) P$ (our results); (2) NGE (Ikeda et al. 2001); $(3,0)$ NGE (calculated as NGE = $P(P+R)$ where $R$ is respiration rate 
mated, because even at $15^{\circ} \mathrm{C}$ and high food concentration $g$ in C. helgolandicus CV amounted to only 0.08 (Harris et al. 2000) and 0.043 (Rey-Rassat et al. 2002a).

After plotting $g$ magnitudes reported by Campbell et al. (2001) against a scale of CW in C. euxinus copepodite stages, we found the correlation between $g$ and CW and calculated daily $P$ as $P=C W\left(\mathrm{e}^{g}-1\right)$. Obtained absolute growth rates (Fig. 10B) increased from $0.00047 \mathrm{mg} \mathrm{C} \mathrm{d}^{-1}$ in CI to $0.0075 \mathrm{mg} \mathrm{C} \mathrm{d}^{-1}$ in CV INs following the equation $P=0.017 \mathrm{CW}^{0.53}$.

$P$ depends upon the respiration rate $(R)$ and the coefficient of net growth efficiency (NGE) according to the equation NGE $=P /(P+R)$. Ikeda et al. (2001) showed that NGE in preadult and adult epipelagic copepods changed from 0.54 to 0.21 when temperature and body weight increased. According to the equations of these authors, at $8^{\circ} \mathrm{C}$ NGE in Calanus euxinus CI to $\mathrm{CV}$ should decrease from 0.47 to 0.37 (Fig. 10B). We estimated age dynamics of NGE in $C$. euxinus from obtained $P$ and $R$ after converting respiration data in $\mu g$ $\mathrm{O}_{2}$ (Fig. 9) to carbon units in $\mu \mathrm{g} \mathrm{C}$ using the coefficient of 0.363 at $R Q=0.97$ (Ikeda et al. 2000), where RQ is respiration quotient. It turned out that at nearly maximum respiration rates in our experiments NGE reduced from 0.77 in early copepodite stages to 0.6 in $\mathrm{CV}$, being close to maximum values for marine copepods (Ikeda et al. 2001). Such a pattern is in accordance with the wellknown conception (Winberg 1968) that in juvenile stages NGE can be close to a theoretical maximum (about 0.8), and then decreases during growth. In the experiments of Petipa (1966), NGE in C. euxinus diminished 10 -fold from 0.55 in CI to 0.056 in CV. Consequently, $P$ magnitudes obtained in our study using the values of $g$ by Campbell et al. (2001) agree with maximum net growth efficiency of marine copepods.

Time dependent changes in $\mathrm{CW}$ of Calanus euxinus at a constant temperature of $8^{\circ} \mathrm{C}$ based on calculated $P$ values are presented in Fig. 11A. According to our calculation, the period from CI to CV PO (when somatic growth predominated over lipid accumulation) amounted to $22 \mathrm{~d}$. Similar median development time (MDT) in CI to CV of Calanus species at $7.6^{\circ} \mathrm{C}(26.2 \mathrm{~d})$ was estimated by Thompson (1982). In the experiments of Vidal (1980b) development time for CII to CV of C. pacificus was equal to $16.7 \mathrm{~d}$, therefore, MDT for CI to $\mathrm{CV}$ should not be less than $20 \mathrm{~d}$. MDT of CI to CV in C. finmarchicus at $8^{\circ} \mathrm{C}$ accounted for 25 and $17 \mathrm{~d}$ at medium and high food concentrations, respectively (Campbell et al. 2001). Tande (1988) reported that in the same species at $6^{\circ} \mathrm{C}$ MDT was $31.8 \mathrm{~d}$. Calculated molt weight increment $(\mathrm{WI})$ as $\mathrm{WI}_{i}=\left(\mathrm{DW}_{i+1}-\mathrm{DW}_{i}\right) /$ $\mathrm{DW}_{i}$ for CI to CIV in C. euxinus ranged from 0.9 to 2.9 in the same way as in other congeneric species (Fig. 11B).

According to our estimation, the period of intensive lipid reserve formation in CV PO to IN phrase lasted

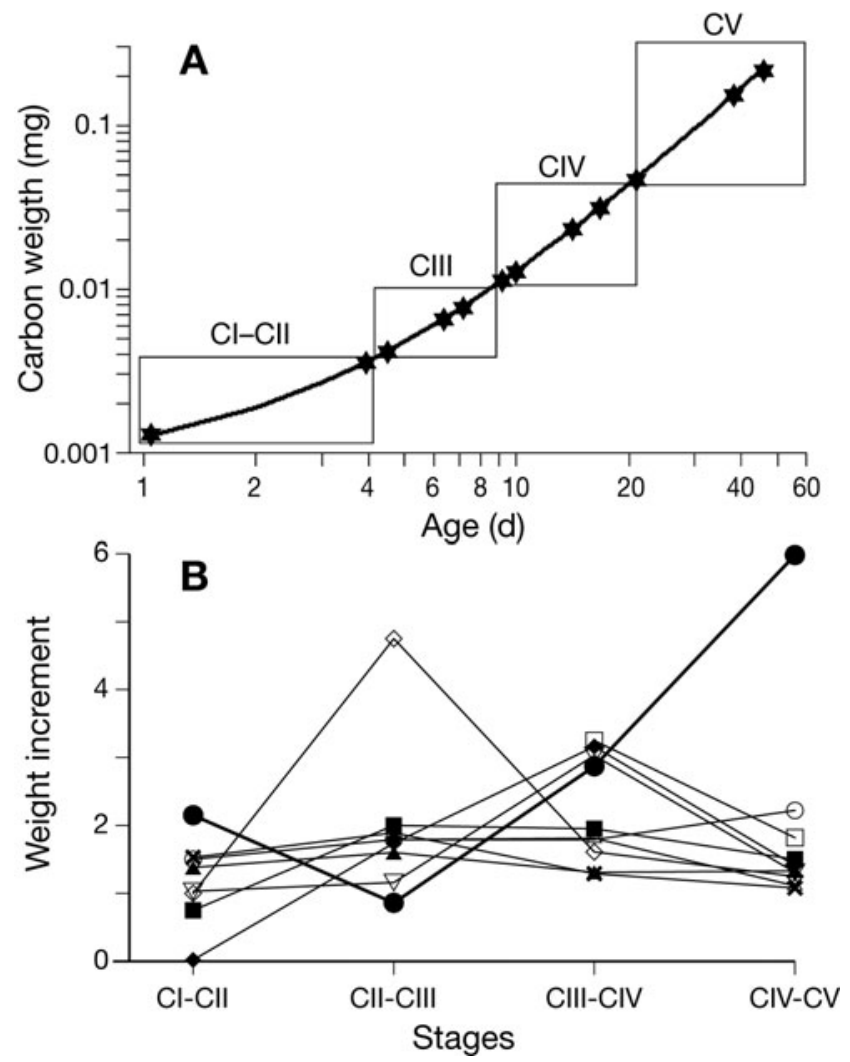

Fig. 11. Calanus euxinus. (A) Growth from CI to intermolt of $\mathrm{CV}$ and (B) mean weight increment $\left[\mathrm{WI}_{i}=\left(\mathrm{WI}_{i+1}-\mathrm{W}_{i}\right) / \mathrm{W}_{i}\right]$ between copepodite stages for $C$. euxinus and sibling species.

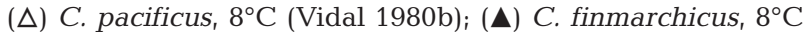
(Fransz \& van Arkel, 1980); (ם) C. finmarchicus, $8^{\circ} \mathrm{C}$ (Carlotti et al. 1993); ( $\square$ ) C. finmarchicus, $10^{\circ} \mathrm{C}$ (Harris et al. 2000); ( $\left.\diamond\right)$ C. finmarchicus, 5.1 to $8.3^{\circ} \mathrm{C}$ (Hygum et al. 2000); (O) C. finmarchicus, $8^{\circ} \mathrm{C}$ (Campbell et al. 2001); ( ) C. helgolandicus, April, the North Sea (Kattner \& Krause, 1987); $(\nabla)$ C. helgolandicus, $15^{\circ} \mathrm{C}$ (Rey-Rassat et al. 2002a); (X) C. sinicus, $10.3^{\circ} \mathrm{C}$ (Uye 1988); (•) C. euxinus, $8^{\circ} \mathrm{C}$ (our data)

$26 \mathrm{~d}$. Although the duration of CV is usually increased (in comparison with other copepodite stages) in copepods accumulating large lipid amounts, we calculated this period to be significantly higher than MDT (9.6 to $12.1 \mathrm{~d}$ ) of $\mathrm{CV}$ in Calanus studied at $\sim 8^{\circ} \mathrm{C}$ (Vidal 1980a, Thompson 1982, Corkett et al. 1986, Campbell et al. 2001). However, one should take into account that in spring in $C$. euxinus $\mathrm{CV}$ stored lipid amount and DFDW increased 17 -fold and 2 -fold, respectively. Therefore, the weight increment of CIV to CV (based on field observations) is equal to 6 , which is nearly 3 times higher than that calculated for $C$. finmarchicus $\mathrm{CV}$ reared under high food conditions (Campbell et al. 2001; see Fig. 1, Table 2 therein).

Finally, generation time from CI to adults in Calanus euxinus during winter-spring homothermy should not be less than $50 \mathrm{~d}$. If we add to this value the duration of development of eggs and nauplii amounting to $16 \mathrm{~d}$ at 
$8^{\circ} \mathrm{C}$ (Corkett et al. 1986, Campbell et al. 2001), total development time for $C$. euxinus will be about $66 \mathrm{~d}$, in contrast to 43.6 and 32 to $46 \mathrm{~d}$ in C. finmarchicus (Corkett et al. 1986), Campbell et al. 2001). However, the development time in $C$. euxinus may be underestimated because we have included in our calculation absolute growth rates which are close to maximum net growth efficiency for preadult and adult copepods (Ikeda et al. 2001).

Our results have shown that we can use obtained development time to estimate Calanus euxinus population dynamics. We found great abundance of newly developed CV POs in the second decade of April. Consequently, the generation of these CVs should appear at the beginning of March, whilst the former generation was formed early in January. Hence, during the cold homothermy in the Black Sea, C. euxinus cannot produce more than 2 generations.

Acknowledgements. The present study was partly supported by a TUBITAK (Turkish Scientific Technical Research Council)-NASU (National Academy of the Ukraine) joint project (107Y001) and NATO Linkage Grants EST 978629 and ESP NUKR 983036. We appreciate the cooperation and help of the staff at the R/V 'Bilim' and 'Knorr' during the cruises. This study is a cooperating project of the Census of Marine Zooplankton (CMarZ), a field project of the Census of Marine Life.

\section{LITERATURE CITED}

Anraku M (1964) Influence of the Cape Cod Canal on the hydrography and on the copepods in Bussards Bay and Cape Cod Bay, Massachusetts. II. Respiration and feeding. Limnol Oceanogr 9:195-206

Arashkevich EG, Drits AV, Timonin AG (1996) Diapause in the life cycle of Calanoides carinatus (Kroyer) (Copepoda, Calanoida). Hydrobiologia 320:197-208

Arashkevich E, Svetlichny L, Gubareva E, Besiktepe S, Gucu AC, Kideys AE (1998) Physiological and ecological studies of Calanus euxinus (Hulsemann) from the Black Sea with comments on its life cycle. In: Ivanov L, Oguz T (eds) Ecosystem modeling as a management tool for the Black Sea. Vol. 2. Kluwer Academic Publishers, Dordrecht, p 351-366

Barnes H, Blackstock J (1973) Estimation of lipids in marine animals and tissues: detailed investigation of the sulphophosvanillin method for 'total' lipids. J Exp Mar Biol Ecol 12:103-118

Besiktepe S (2001) Diel vertical distribution and herbivory of copepods in the south-eastern part of the Black Sea. J Mar Syst 28:281-301

Besiktepe S, Telli M (2004) Egg production and growth rates of Calanus euxinus (Copepoda) in the Black Sea. J Plankton Res 26:571-578

Besiktepe S, Unsal M (2000) Population structure, vertical distribution and diel migration of Sagitta setosa (Chaetognatha) in the south-western part of the Black Sea. J Plankton Res 22:669-683

Besiktepe S, Kideys AE, Unsal M (1997) In situ grazing pressure and diel vertical migration of female Calanus euxinus in the Black Sea. Hydrobiologia 363:323-332
Besiktepe S, Svetlichny L, Yuneva T, Romanova Z, Shulman G (2005) Diurnal gut pigment rhythm and metabolic rate of Calanus euxinus in the Black Sea. Mar Biol 146: 1189-1198

Bonnet D, Richardson A, Harris R, Hirst A and others (2005) An overview of Calanus helgolandicus ecology in European waters. Prog Oceanogr 65:1-53

Campbell RG, Wagner MM, Teegarden GJ, Boudreau CA, Durbin EG (2001) Growth and development rates of the copepod Calanus finmarchicus reared in the laboratory. Mar Ecol Prog Ser 221:161-183

Carlotti F, Krause M, Radach G (1993) Growth and development of Calanus finmarchicus related to the influence of temperature: experimental results and conceptual model. Limnol Oceanogr 38:1125-1134

Ceballos S, Cabal JA, Álvarez-Marqués F (2004) Reproductive strategy of Calanoides carinatus and Calanus helgolandicus during a summer upwelling event off NW Spain. Mar Biol 145:739-750

Corkett CJ, McLaren IA, Sevigny JM (1986) The rearing of the marine calanoid copepods Calanus finmarchicus (Gunnerus), C. glacialis Jaschnov and C. hyperboreus Krøyer with comment on the equiproportional rule. Syllogeus 59:539-546

Crain JA, Miller CB (2001) Effects of starvation on intermolt development in Calanus finmarchicus copepodites: a comparison between theoretical models and field studies. Deep-Sea Res II 48:551-566

> Eker-Develi E, Kideys AE (2003) Distribution of phytoplankton in the southern Black Sea in summer 1996, spring and autumn 1998. J Mar Syst 39:203-211

Fleminger A, Hulsemann K (1987) Geographical variation in Calanus helgolandicus s.l. (Copepoda, Calanoida) and evidence of recent speciation of the Black Sea population. Biol Oceanogr 5:43-81

Flint MV (1989) Vertical distribution of mass mesoplankton species in lower layers of aerobic zone in relation to the structure of oxygen field. In: Vinogradov ME, Flint MV (eds) Structure and productional characteristics of planktonic populations in the Black Sea. Nauka, Moscow, p 187-213 (in Russian)

Folch J, Lees M, Sloane-Stanley GH (1957) A simple method for the isolation and purification of total lipids from animal tissues. J Biol Chem 226:497-509

Fransz HG, van Arkel WG (1980) Zooplankton activity during and after the phytoplankton spring bloom at the central station in the FLEX-box, northern North Sea, with a special reference to the calanoid copepod Calanus finmarchicus (Gunn.). 'Meteor'. Forsch Ergeb Ser A 22:113-121

> Håkanson JL (1989) Analysis of lipid components for determining the condition of anchovy larvae, Engraulis mordax. Mar Biol 102:143-151

Harris RP, Irigoien X, Head RN, Rey C and others (2000) Feeding, growth, and reproduction in the genus Calanus. ICES J Mar Sci 57:1708-1726

Hulsemann K (1991) Calanus euxinus, new name, a replacement name for Calanus ponticus Karavaev, 1894 (Copepoda: Calanoida). Proc Biol Soc Wash 104:620-621

> Hygum BH, Rey C, Hansen K, Tande K (2000) Importance of food quantity to structural growth rate and neutral lipid reserves accumulated in Calanus finmarchicus. Mar Biol 136:1057-1073

Ikeda T, Torres JJ, Hernandes-Leon S, Geiger SP (2000) Oxygen consumption as an index of metabolism. In: Harris R, Wiebe P, Lenz J, Skjoldal HR, Huntley M (eds) JCES Zooplankton methodology manual. Academic Press, London, p 453-532 
Ikeda T, Kanno Y, Ozaki K, Shinada A (2001) Metabolic rates of epipelagic marine copepods as a function of body mass and temperature. Mar Biol 139:587-596

Jaschnov VA (1955) Morphology, distribution and systematics of Calanus finmarchicus s.l. Zool Zh 34:1210-1223 (in Russian with English abstract)

Johnson CL (2004) Seasonal variation in the molt status of an oceanic copepod. Prog Oceanogr 62:15-32

Karavaev V (1894) Contributions to the Crustacean pelagic fauna of the Black Sea. Kiev Universitet. Obshestvo estestvoispitatelei, Zapiski 13:35-61

Kates M (1975) Techniques of lipidology. Mir, Moscow (in Russian with English abstract)

Kattner G, Krause M (1987) Changes in lipids during the development of Calanus finmarchicus s.l. from copepodid I to adult. Mar Biol 96:511-518

Lewis RW (1970) The densities of 3 classes of marine lipids in relation to their possible role as hydrostatic agents. Lipids 5:151-153

Marker T, Andreassen P, Arashkevich E, Hansen BW (2003) Lipid deposition and sexual maturation in cohorts of Calanus finmarchicus (Gunnerus) originating from Bergen $\left(60^{\circ} \mathrm{N}\right)$ and Tromsø $\left(69^{\circ} \mathrm{N}\right)$ reared in Tromsø, Norway. Mar Biol 143:283-296

Miller CB, Morgan CA, Prahl FG, Sparrow MA (1998) Storage lipids of the copepod Calanus finmarchicus from Georges Bank and the Gulf of Maine. Limnol Oceanogr 43:488-497

Miller CB, Crain JA, Morgan CA (2000) Oil storage variability in Calanus finmarchicus. ICES J Mar Sci 57:1786-1799

Ohman MD (1988) Sources of variability in measurements of copepod lipids and gut fluorescence in the California Current coastal zone. Mar Ecol Prog Ser 42:143-153

Papadopoulos LN, Peijnenburg KTCA, Luttikhuizen PC (2005) Phylogeography of the calanoid copepods Calanus helgolandicus and C. euxinus suggests Pleistocene divergences between Atlantic, Mediterranean, and Black Sea populations. Mar Biol 147:1353-1365

Pavlova EV, Minkina NI (1987) Weight-specific respiration of marine planktonic animals with different activity. J Gen Biol 48:92-103 (in Russian with English abstract)

Peterson WT (1986) Development, growth, and survivorship of the copepod Calanus marshallae in the laboratory. Mar Ecol Prog Ser 29:61-72

Petipa TS (1966) On energy balance of Calanus helgolandicus (Claus) in the Black Sea. In: Ivlev VS (ed) Physiology of marine animals. Nauka, Moscow, p 60-81 (in Russian)

Petipa TS (1981) The trophodynamics of copepods in the marine planktonic communities. Naukova Dumka, Kiev (in Russian)

Polischuk VV (1984) On significant lift of the Black Sea level in the Late Holocene and origin of northern elements in its fauna. Hydrobiol J 20:3-13 (in Russian with English abstract)

> Rey-Rassat C, Irigoien X, Harris R, Head R, Carlotti F (2002a) Growth and development of Calanus helgolandicus reared in the laboratory. Mar Ecol Prog Ser 238:125-138

Rey-Rassat C, Irigoien X, Harris R, Carlotti F (2002b) Energetic cost of gonad development in Calanus finmarchicus and C. helgolandicus. Mar Ecol Prog Ser 238:301-306

Rey-Rassat C, Bonnet D, Irigoien X, Harris R, Head R, Carlotti F (2004) Secondary production of Calanus helgolandicus in the Western English Channel. J Exp Mar Biol Ecol 313: $29-46$

Sargent JR, Henderson RJ (1986) Lipids. In: Corner EDS, O'Hara SCM (eds) The biological chemistry of marine copepods. Clarendon Press, Oxford, p 59-164
Sargent JR, McIntosh R (1974) Studies on the mechanism of biosynthesis of wax esters in Euchaeta norvegica. Mar Biol 25:271-277

Sazhina LI (1987) Reproduction, growth, productivity of marine Copepoda. Naukova Dumka, Kiev (in Russian)

Svetlichny LS (1983) Calculation of planktonic copepod biomass by means of coefficients of proportionality between volume and linear dimensions of the body. Ecologia Morja 15:46-58 (in Russian with English abstract)

Svetlichny LS, Hubareva ES (2005) The energetics of Calanus euxinus: locomotion, filtration of food and specific dynamic action. J Plankton Res 27:671-682

Svetlichny LS, Hubareva ES, Arashkevich EG (1998) Physiological and behavioural response to hypoxia in active and diapausing stage V copepodites of Calanus euxinus. Arch Hydrobiol Spec Issues Adv Limnol 52:507-519

Svetlichny LS, Kideys AE, Hubareva ES, Besiktepe S, Isinibilir M (2006) Development and lipid storage in Calanus euxinus from the Black and Marmara seas: variabilities due to habitat conditions. J Mar Syst 59:52-62

Tande KS (1988) Aspects of developmental and mortality rates in Calanus finmarchicus related to equiproportional development. Mar Ecol Prog Ser 44:51-58

Thompson BM (1982) Growth and development of Pseudocalanus elongatus and Calanus sp. in the laboratory. J Mar Biol Assoc UK 62:359-372

> Unal E, Frost BW, Armbrust V, Kideys AE (2006) Phylogeography of Calanus helgolandicus and the Black Sea copepod Calanus euxinus, with notes on Pseudocalanus elongatus (Copepoda, Calanoida). Deep-Sea Res II 53:1961-1975

Uye S (1988) Temperature-dependent development and growth of Calanus sinicus (Copepoda: Calanoida) in the laboratory. Hydrobiologia 167-168:285-293

> Ventura M (2006) Linking biochemical and elemental composition in freshwater and marine crustacean zooplankton. Mar Ecol Prog Ser 327:233-246

Vidal J (1980a) Physioecology of zooplankton. I. Effects of phytoplankton concentration, temperature, and body size on the growth rate of Calanus pacificus and Pseudocalanus sp. Mar Biol 56:111-134

> Vidal J (1980b) Physioecology of zooplankton. II. Effects of Phytoplankton concentration, temperature, and body size on the development and molting rates of Calanus pacificus and Pseudocalanus sp. Mar Biol 56:135-146

- Vidal J (1980c) Physioecology of zooplankton. III. Effects of phytoplankton concentration, temperature and body size on the metabolic rate of Calanus pacificus. Mar Biol 56: 195-202

Vinogradov ME, Arashkevich EG, Ilchenko SV (1992a) The ecology of the Calanus ponticus population in the deeper layer of its concentration in the Black Sea. J Plankton Res $14: 447-458$

Vinogradov ME, Sapozhnikov VV, Shushkina EA (1992b) The Black Sea ecosystem. Nauka, Moskow (in Russian with English abstract)

Vinogradov ME, Shushkina EA, Musaeva EI, Nikolaev GG (1992c) Vertical distribution of the Black Sea mezosooplankton in winter 1991. In: Vinogradov ME (ed) Ecosystem of the open Black sea in winter (based on data of the 21st cruise of the R/V 'Vityaz', February 9-April 8, 1991). Mir, Moscow, p 103-119 (in Russian)

Vinogradov ME, Shiganova TA, Khoroshilov VS (1995) The state of the main organisms in a plankton community in the Black Sea in 1993. Oceanology (Mosc) 35:387-391

Vinogradov ME, Lebedeva LP, Vinogradov GM, Musaeva EI and others (2005) Monitoring of the pelagic communities of the northeastern part of the Black Sea in 2004: macro- 
and mesoplankton. Oceanology 45:381-392

Vinogradov ME, Lebedeva LP, Lukasheva TA, Anokhina LA (2006) Condition of coastal mesoplankton communities in the northeastern area of the Black sea in 2005. Oceanology 46:817-826

Williams R, Robins DB (1982) Effects of preservation on wet weight, dry weight, nitrogen and carbon contents of Calanus helgolandicus (Crustacea: Copepoda). Mar Biol 71: 271-281

Winberg GG (1968) Growth rate and intensity of metabolism in animals. Usp Sovrem Biol 6:274-293 (in Russian with

Editorial responsibility: Hans Heinrich Janssen, Oldendorf/Luhe, Germany
English abstract)

Yuneva TV, Svetlichny LS, Schepkina AM (1997) Lipid composition and locomotory activity of diapausing Calanus euxinus (Copepoda). Hydrobiol J 33:74-84 (in Russian with English abstract)

Yuneva TV, Svetlichny LS, Yunev OA, Romanova ZA and others (1999) Nutritional condition of female Calanus euxinus from cyclonic and anticyclonic regions of the Black Sea. Mar Ecol Prog Ser 189:195-204

Zaitsev YuP (2006) An introduction on the Black Sea ecology. Aven, Odessa (in Russian with English abstract)

Submitted: January 10, 2008; Accepted: September 17, 2008 Proofs received from author(s): December 18, 2008 